Article

\title{
Gems and Placers-A Genetic Relationship Par Excellence
}

\author{
Harald G. Dill
}

Mineralogical Department, Gottfried-Wilhelm-Leibniz University, Welfengarten 1, D-30167 Hannover, Germany; haralddill@web.de

Received: 30 August 2018; Accepted: 15 October 2018; Published: 19 October 2018

Abstract: Gemstones form in metamorphic, magmatic, and sedimentary rocks. In sedimentary units, these minerals were emplaced by organic and inorganic chemical processes and also found in clastic deposits as a result of weathering, erosion, transport, and deposition leading to what is called the formation of placer deposits. Of the approximately 150 gemstones, roughly 40 can be recovered from placer deposits for a profit after having passed through the "natural processing plant" encompassing the aforementioned stages in an aquatic and aeolian regime. It is mainly the group of heavy minerals that plays the major part among the placer-type gemstones (almandine, apatite, (chrome) diopside, (chrome) tourmaline, chrysoberyl, demantoid, diamond, enstatite, hessonite, hiddenite, kornerupine, kunzite, kyanite, peridote, pyrope, rhodolite, spessartine, (chrome) titanite, spinel, ruby, sapphire, padparaja, tanzanite, zoisite, topaz, tsavorite, and zircon). Silica and beryl, both light minerals by definition (minerals with a density less than $2.8-2.9 \mathrm{~g} / \mathrm{cm}^{3}$, minerals with a density greater than this are called heavy minerals, also sometimes abbreviated to "heavies". This technical term has no connotation as to the presence or absence of heavy metals), can also appear in some placers and won for a profit (agate, amethyst, citrine, emerald, quartz, rose quartz, smoky quartz, morganite, and aquamarine, beryl). This is also true for the fossilized tree resin, which has a density similar to the light minerals. Going downhill from the source area to the basin means in effect separating the wheat from the chaff, showcase from the jeweler quality, because only the flawless and strongest contenders among the gemstones survive it all. On the other way round, gem minerals can also be used as pathfinder minerals for primary or secondary gemstone deposits of their own together with a series of other non-gemmy material that is genetically linked to these gemstones in magmatic and metamorphic gem deposits. All placer types known to be relevant for the accumulation of non-gemmy material are also found as trap-site of gemstones (residual, eluvial, colluvial, alluvial, deltaic, aeolian, and marine shelf deposits). Running water and wind can separate minerals according to their physical-chemical features, whereas glaciers can only transport minerals and rocks but do not sort and separate placer-type minerals. Nevertheless till (unconsolidated mineral matter transported by the ice without re-deposition of fluvio-glacial processes) exploration is a technique successfully used to delineate ore bodies of, for example, diamonds. The general parameters that matter during accumulation of gemstones in placers are their intrinsic value controlled by the size and hardness and the extrinsic factors controlling the evolution of the landscape through time such as weathering, erosion, and vertical movements and fertility of the hinterland as to the minerals targeted upon. Morphoclimatic processes take particular effect in the humid tropical and mid humid mid-latitude zones (chemical weathering) and in the periglacial/glacial and the high-altitude/mountain zones, where mechanical weathering and the paleogradients are high. Some tectono-geographic elements such as unconformities, hiatuses, and sequence boundaries (often with incised valley fills and karstic landforms) are also known as planar architectural elements in sequence stratigraphy and applied to marine and correlative continental environments where they play a significant role in forward modeling of gemstone accumulation. The present study on gems and gemstone placers is a reference example of fine-tuning the "Chessboard classification scheme of mineral deposits" (Dill 2010) and 
a sedimentary supplement to the digital maps that form the core of the overview "Gemstones and geosciences in space and time" (Dill and Weber 2013).

Keywords: gemstones; placer; heavy and light minerals; landforms; climate; geodynamic setting

\section{Introduction-Coupling Gemstones and Placer Deposits}

Inorganic raw materials and mineral deposits are subdivided in the most convenient way using a tripartite classification scheme into (1) ore minerals and metallic resources, (2) industrial minerals and rocks, and (3) gemstones and ornamental stones [1]. Category 1 is self explanatory and serves as a resource for metals like $\mathrm{Pb}, \mathrm{Zn}$, and $\mathrm{Fe}$, category 2 comprises mineral raw materials which by virtue of their physical and chemical properties such as insulation capacity or fire-resistant properties are essential for human beings, e.g., perlite, kaolin, bentonite, zeolites, diatomite, or vermiculite, while category 3 stands out by the aesthetic value of its items, like a diamond in a necklace or a statue sculptured out of a block of marble. Gems and gemstones as part of category 3 are known for their elevated hardness expressed by the Mohs hardness numbers. The three top scorers in the hardness scale of Mohs diamond (10), corundum (9), and topaz (8) are renowned gemstones (Table 1). All but three gemstones (varieties of beryl, quartz modifications, amber) are heavy minerals by definition (minerals with a density greater than $2.8-2.9 \mathrm{~g} / \mathrm{cm}^{3}$, which is the density range of the most common rock-forming minerals, quartz, plagioclase, alkaline feldspar, and calcite) (Table 1).

Placer deposits are a subtype of clastic sedimentary rocks composed of rock fragments or mineral particles which were transported from their source by water, wind, ice, or simply by gravity to the depocenter. While common siliciclastic rocks have the light minerals feldspar s.s.s. (=solid solution series), quartz, phyllosilicates, and carbonate minerals as main constituents and contain heavy minerals only as accessory minerals, and in placer deposits, the latter group of minerals prevails over light minerals, in places, to such an extent that they can be mined for the three commodity groups mentioned at the beginning, e.g., magnetite placers (ore), phosphate placers (industrial minerals), and diamond placers (gemstones) (see Section 3.8). Gemstones fulfill all physical requirements to survive the transport from the source to the depositional environment; they have the hardness to resist chemical weathering in the provenance area, to stand the attrition and pass through the comminution processes on transport so as to appear at the site of deposition as a raw material to be mined for a profit. The separation of the gemstones from the diluting thrash or gangue minerals (quartz, feldspar) by their different specific gravities and hardness takes full effect leading to a grain size and quality justifying the minerals being called a gemstone of economic relevance for cutters and jewelers-jeweler quality (Table 1, Figure 1). Lower qualities are recovered, in places, for the showcase attractive to mineral dealers and collectors, and the lowest grade can still be harnessed owing to its hardness as an industrial mineral, used as abrasives in the industry, e.g., corundum. 
Table 1. Gem minerals found in placer deposits, their physical properties relevant for their emplacement clastic haloes around their source rocks and the sedimentary traps. The gem placer deposits are subdivided according to the "Chessboard classification scheme of mineral deposits" [1]—See Appendix A, so as to assist their assignment to the overall concentration processes of elements, minerals, and rocks during magmatic, metamorphic, and sedimentary processes.

\begin{tabular}{|c|c|c|c|c|}
\hline $\begin{array}{l}\text { Element (for General } \\
\text { Classification Scheme see [1]) }\end{array}$ & Mineral & Type & $\begin{array}{l}\text { Density (Mean) } \\
\mathrm{kg} / \mathrm{m}^{3}\end{array}$ & Hardness \\
\hline Beryllium & $\begin{array}{l}\text { Beryl and its varieties emerald, } \\
\text { aquamarine, heliodor, morganite, } \\
\text { goshenite, pezzottaite (a) Chrysoberyl (b) }\end{array}$ & $\begin{array}{l}\text { Residual, colluvial, alluvial (fluvial). } \\
\text { Argillaceous (kaolin) regolith }\end{array}$ & $\begin{array}{l}\text { (a) } 2.8 \\
\text { (b) } 3.7\end{array}$ & $\begin{array}{l}\text { (a) } 7.5-8.0 \\
\text { (b) } 8.5\end{array}$ \\
\hline Boron & Tourmaline (further minerals see Table 2) & $\begin{array}{l}\text { Residual to colluvial placers in stream sediments and marine } \\
\text { placer deposits as byproduct, useful as proximity } \\
\text { indicator/pathfinder }\end{array}$ & 3.2 & 7.5 \\
\hline Fluorine & Topaz & $\begin{array}{l}\text { Residual to colluvial placers in stream sediments useful as } \\
\text { proximity indicator/pathfinder }\end{array}$ & 3.6 & 8.0 \\
\hline Phosphorous & Apatite & Eluvial, colluvial, alluvial placers & 3.2 & 5.0 \\
\hline Zirconium & Zircon (hyacinth) & $\begin{array}{l}\text { Gemstone: residual to alluvial placers. } \\
\text { Industrial minerals: marine placers }\end{array}$ & 4.7 & 7.5 \\
\hline Garnet group & $\begin{array}{l}\text { Grossular (hessonite, tsavorite), spessartine, } \\
\text { pyrope and its variety rhodolite, andradite } \\
\text { (demantoid), almandine }\end{array}$ & $\begin{array}{l}\text { Gemstone: residual to alluvial placers. } \\
\text { Industrial minerals: also in marine placers }\end{array}$ & 4.2 & $7.0-8.0$ \\
\hline Corundum & Ruby, sapphire, padparaja & Residual, eluvial, colluvial alluvial-fluvial & 4.1 & 9.0 \\
\hline Spinel & Spinel group minerals & See corundum & 3.6 & 8.0 \\
\hline Diamonds & Diamond & $\begin{array}{l}\text { Residual, eluvial, colluvial, alluvial-fluvial, marine and } \\
\text { aeolian modern and paleoplacers deposits }\end{array}$ & 3.5 & 10 \\
\hline Silica & $\begin{array}{l}\text { Rock crystal, agate, amethyst, citrine, } \\
\text { quartz, rose quartz, smoky quartz }\end{array}$ & $\begin{array}{l}\text { Alluvial-fluvial placers (amethyst, agate, rock crystal). } \\
\text { Residual placer (double terminated rock crystal) }\end{array}$ & 2.6 & 7.0 \\
\hline Chromium & Cr titanite (a), Cr diopside (b) & $\begin{array}{l}\text { Colluvial-alluvial-fluvial placers (Cr diopside), ((Cr)-titanite) } \\
\text { short distance of transport, useful as pathfinder }\end{array}$ & $\begin{array}{l}\text { (a) } 3.5 \\
\text { (b) } 3.4\end{array}$ & $\begin{array}{l}\text { (a) } 5.0-5.5 \\
\text { (b) } 6.0\end{array}$ \\
\hline Olivine s.s.s. & Peridote & $\begin{array}{l}\text { Colluvial-alluvial-fluvial-marine placers only in case of a high } \\
\text { ratio of uplift/weathering and/or short distance of transport }\end{array}$ & 3.3 & $6.5-7.0$ \\
\hline Epidote s.s.s. & Tanzanite & Colluvial-alluvial & 3.3 & 6.5 \\
\hline Lithium & Kunzite, hiddenite & $\begin{array}{l}\text { Residual to alluvial placers, swiftly decomposes to } \\
\text { argillaceous material }\end{array}$ & 3.2 & $6.5-7.0$ \\
\hline Organic compounds & Amber & Fluvial, marine placers & 1.1 & $2.0-2.5$ \\
\hline
\end{tabular}




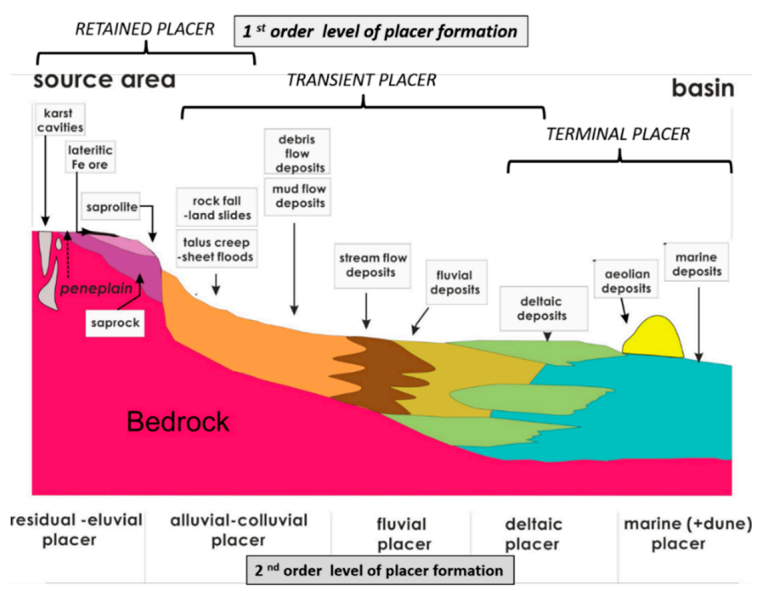

Figure 1. Cartoon to show the different types of placer deposits from the source area to the basin, from the weathering mantle on the top of the exposed bedrock through the continental terrigenous lithofacies types into the marine lithofacies. Glacial and fluvial-glacial lithofacies types because of the minor relevance for placer deposits in terms of separating light and heavy minerals are not shown in the cartoon.

\section{Placer-Environments of Formation and Sedimentary Processes}

\subsection{Subdivision of Placer Deposits}

Placer deposits are surficial mineral deposits resulting from mechanical processes operative in various depositional environments from the source to the basin (Figure 1). These accumulations composed, predominantly of heavy minerals have been investigated intensively by different authors paying most attention to the depositional environments [2-17]. Concluding from the aforementioned studies, a first-order subdivision may be achieved into modern placers and paleoplacers. Modern placers are unconsolidated to loosely bound accumulations embedded into mostly Neogene to Quaternary near surface deposits of different clastic lithofacies types and lacking post-sedimentary diagenetic alteration. The conglomerates at Blind River-Elliot Lake, Canada, and Witwatersrand, South Africa occur in stratigraphic series that developed when the Earth's atmosphere was different from today's oxidizing conditions and called paleoplacers. Their quartz pebble conglomerates formed from the Archaean to the Early Proterozoic (3100-2200 Ma), some also extending into the Middle Proterozoic such as the Tarkwa (1900 Ma). World-class deposits are at Witwatersrand, South Africa, Elliot Lake, Canada, Sierra do Jacobina, Brazil, Tarkwa, Ghana, and the Guyana Shield area in Colombia

Milesi et al., Malitc et al., and Frimmel [18-20]. Paleoplacers of Precambrian age may grade into modern placers through a wide range of Mesozoic and Cenozoic heavy mineral repositories which are the subject of exploration geologists mainly targeting upon diamond, as shown in some case histories of gem deposits discussed later in the study. Besides gold they also gave host to diamonds and colored gemstones but predominantly act as a protore and as such agree with the binary classification scheme of Stanaway [21].

The second level of subdivision in the hierarchy does not reflect a function of age, but depicts the depositional environment. A "catena" of placer deposits can be established from source to basin (Figure 1): (1) Residual and eluvial placers, (2) colluvial, (3) alluvial-fluvial placers, (4) deltaic placers, and (5) marine and aeolian placers (Figure 1). In the succeeding sections, the various environments are described in more detail with special reference to the accumulation of gemstones. Due to the bimodal distribution of gemstones, which reveals that one part of them is preferably laid down near the source area, and another at the very end of the "catena" in the marine basins, the environmental analysis in Section 2.2 places its emphasis predominantly on the most proximal and most distal lithofacies types of the "catena", which literally translates into the two groups of gemstones, the colored gems, and the diamonds (Figure 1). 


\subsection{Depositional Environments of Gemstone Placers}

\subsubsection{Residual-Eluvial Placers}

Residual-eluvial placers mirror the start-up of a placer development. Magmatic, metamorphic, or sedimentary bedrocks (parent material of the gemstones) undergo chemical and/or mechanical weathering leading to a disintegration of the source rocks and a gradual liberation of the rock-forming minerals highly resistant to supergene alteration from those more vulnerable to it. Water removes the "trash minerals" from the weathering mantle and washes the chemical compounds in the meteoric fluids out of the regolith resultant in an in-situ concentration of heavy minerals (Figure $2 \mathrm{a}-\mathrm{c}$ ). The weathering profile in the statu nascendi consists of the fresh parent rock that is converted into a saprock, still displaying the structure and texture of the primary rock and that is overlain by a saprolite reflecting together with ferricretes on top the most intensive stage of chemical weathering (Figure 2a). The saprolite on top of an ultrabasic rocks may be enriched in precious corundum, which is accompanied by anatase, brookite, rutile, zircon, and Fe oxide-hydrates after flushing out the phyllosilicates emplaced during supergene alteration (Figure 2b,c). Therefore, to show the intensity of weathering and the transition from residual placers into parautochthonous colluvial ones Ti dioxides and zircon are excellent marker minerals and the chemical compounds of $\mathrm{TiO}_{2}$ and $\mathrm{Zr}$ well reflect this reworking process in the chemolog (Figure 2c). The current chemolog is representative of a composite weathering profile with hiatuses marked by the arrowheads where loose weathering loam was transported away by hill wash downslope. Such breaks in weathering and sedimentation are planar elements guiding precious corundum (Section 3.7) and diamond accumulation (Section 3.8).

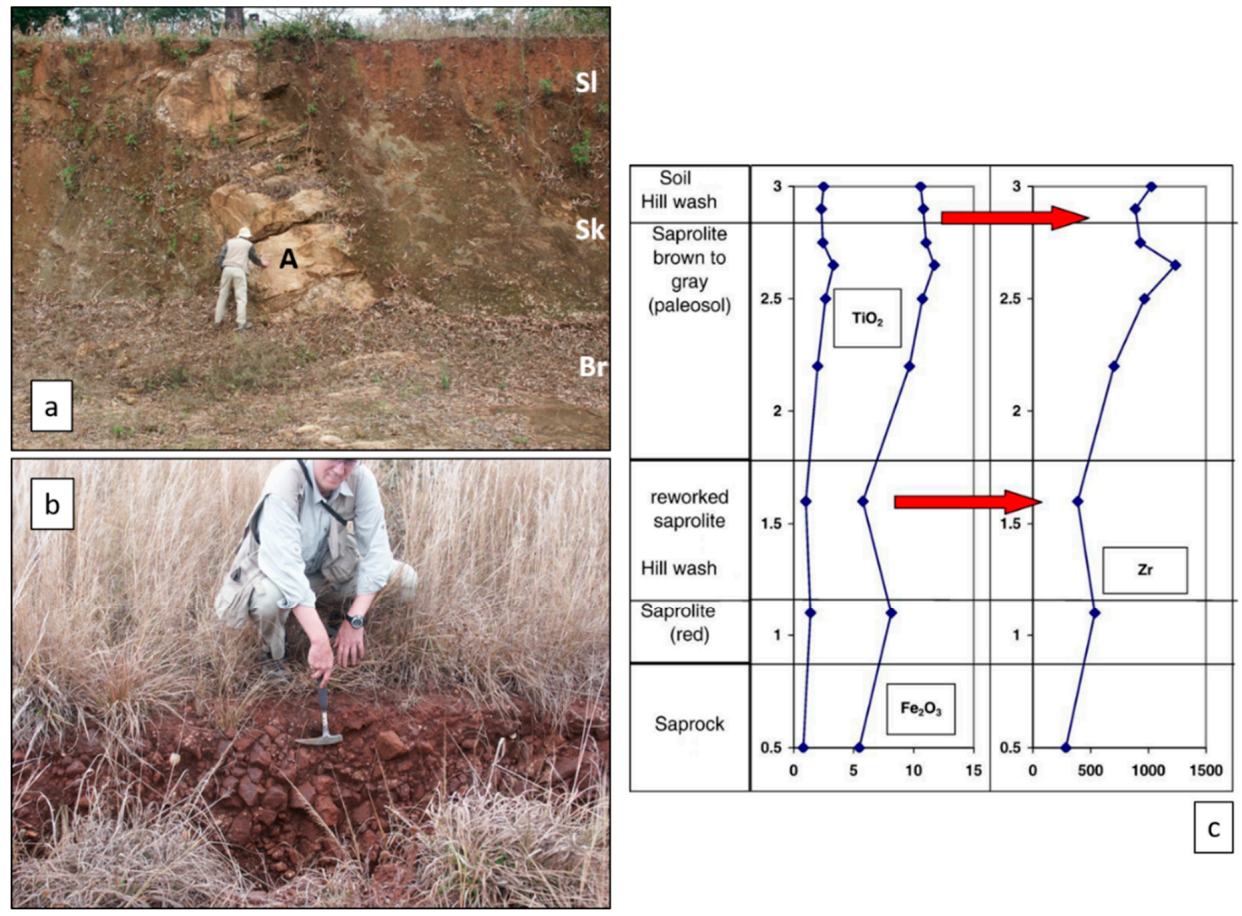

Figure 2. Residual placers from the savannah in Malawi. (a) Penetration of weathering as a function of bedrock lithology. The migmatitic $\mathrm{K}$ gneiss $(\mathrm{Br})$ is more susceptible to weathering than the aplitic dyke (A) producing a weathering mantle of saprock (Sk) and saprolite (Sl). The meteoric fluids easily penetrated the metamorphic rocks along the planes of foliation which are very narrowly spaced and almost vertical. (b) Rusty red saprolite with relic corestones of metapyroxenite. The weathering loam hosts pale green and white sapphire crystals disseminated in a case-hardened duricrust. (c) Chemolog along a road cut measuring $3 \mathrm{~m}$ in depth illustrating the transition from a residual placer to a colluvial placer. Rutile (see $\mathrm{TiO}_{2}$ contents) and zircon (see $\mathrm{Zr}$ contents) are cast in the role of marker minerals. The dip-slope motion of the weathering material is denoted by the red arrowheads. 


\subsubsection{Colluvial Placers}

Colluvial placers form along hill slopes different with regard to their dip simply as a function of gravity as the most driving force and the availability of water as the decisive modifier of the various processes [22] (Figure 3a). Dip of slope and the extent to which the substrate is soaked with water controlling the speed of deposition. Sediment transport by means of talus or soil creep does not contribute much to the build-up of placers, as is the case with simple heave. Heave is a process causing slope instability of a certain kind of "swelling" soil and overburden that are abundant in clay minerals, particularly smectite. These fine-grained rocks lie on the opposite end of the grain-size scale of the common host rocks of gemstone placers and therefore can be cast aside in a treatment of colluvial placers.
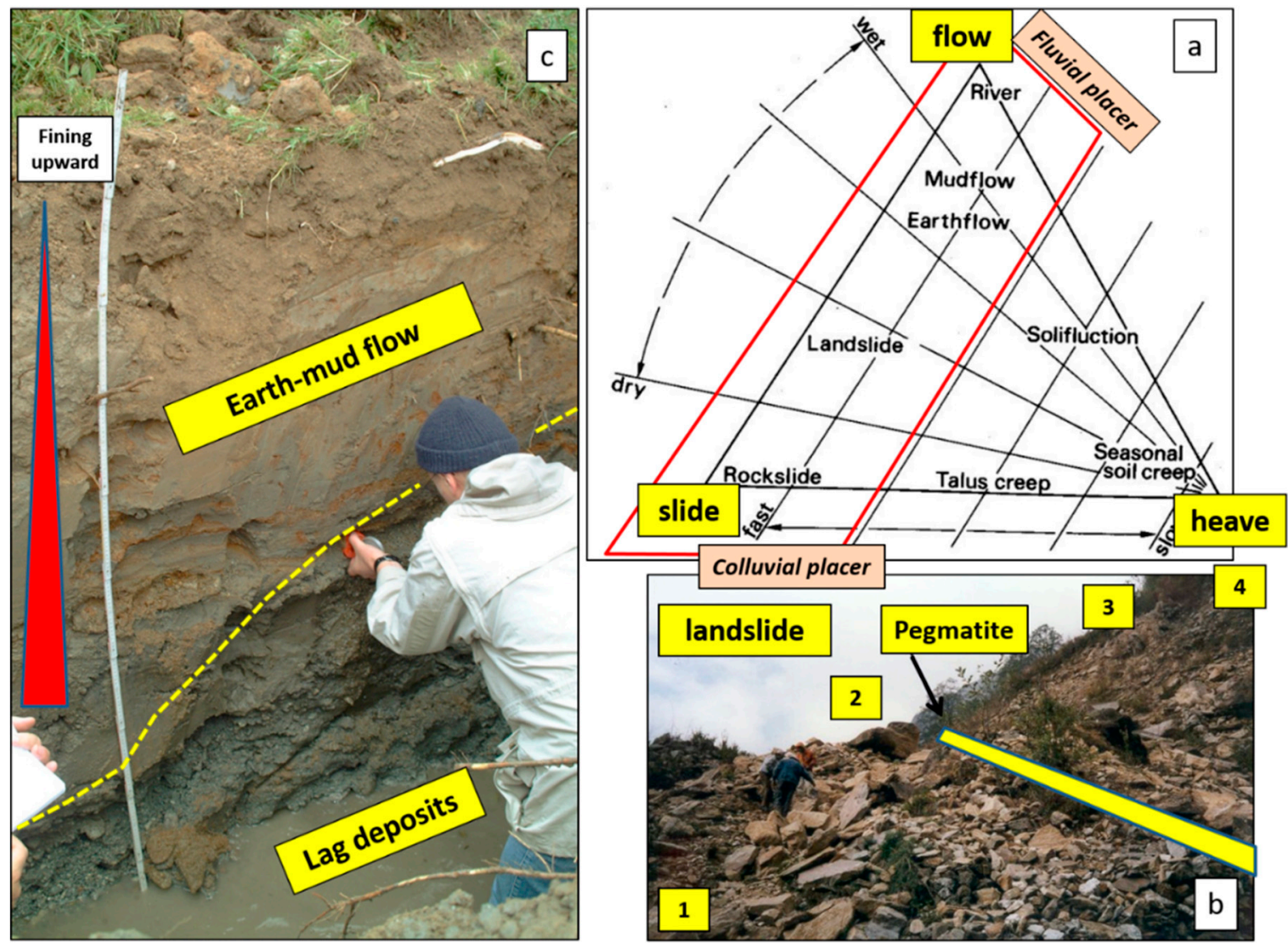

Figure 3. Colluvial placers (a) A triplot to show the various forms of colluvial processes and deposits as a function of wetness of the material and the velocity of mass wasting (slightly modified after [22]). The area framed with the red line is the area essential for the accumulation of gemstones attaining a size of economic importance. (b) The topmost part of a pegmatite layer which was worked for tourmaline is exposed and partly covered by rubble of a landslide, Nepal. The different zones are marked: (1) Zone of accumulation = colluvial tourmaline placer, (2) transverse ridge, (3) zone of depletion, and (4) main scarp (photograph taken by Tamrakar). The placer deposit is situated on a steep hill slope in the Himalaya, Nepal (c) A trench dug into earth-mud flow bearing a colluvial "nigrine" placer (nigrine = intergrowth of rutile and ilmenite). The upper boundary is marked by the yellow dashed line. The image shows sampling for OSL (optically stimulated luminescence) age dating of the colluvial placer, SE Germany. The colluvial processes are operative along the slopes of a small river perpendicular to the thalweg of the fluvial drainage system.

The processes relevant for gemstone placers are fast mass wasting processes, as demonstrated by the rubble in the zone of accumulation of a landslide underneath the tourmaline-bearing pegmatite which is synonymous with the zone of exploitation since it contains the "gemstone placer ore", whereas 
the primary gemstone deposit is uneconomic because of little or no accessibility (Figure 3a,b). It is a fast mass wasting process with little water involved with the zone of depletion marking the source area and the outcrop of the pegmatite marking the transverse ridge bulldozed over (Figure $3 b$ ). In the trench on display in Figure 3c, the geologists are faced with an entirely different situation. The driving force behind these colluvial processes is gravity, but the material of mud and gravel is soaked with water. The earth-mud flow bearing a colluvial "nigrine" and cassiterite accumulation evolved perpendicular to the thalweg of a fluvial drainage system and as a consequence of the steep slope provoked the fast motion of the "slurry" responsible for the coarse lag deposits exposed at the final depth of the trench $[23,24]$. To clearly demonstrate which process colluvial or fluvial was instrumental in the emplacement of the placer deposits a quantitative recording of the orientation of the longitudinal axes of clasts and plotting them in pole diagrams (situmetry) is recommended. It goes without saying that pure end member types such as pure colluvial or fluvial placer system are the exception rather than the rule in nature particular to the section of retained and transient placers (Figures 1 and 3a). To guarantee the emplacement of a colluvial placer of significance as to the amount of heavy minerals and their particle size the velocity of the mass wasting processes is paramount. Talus creep and heave are not efficacious in the production of significant accumulations of colluvial gemstone placers as stated above.

\subsubsection{Alluvial-Fluvial Placers}

The alluvial-fluvial placer deposits intertongue with the aforementioned colluvial deposits with stream flow accumulation at their most distal position or overlap with each other during a stepwise uplift of the hinterland when the system becomes wetter (Figure 1, Figure 3a, and Figure 4). The alluvial-fluvial systems play a major part in the formation of sedimentary concentrations of the top-score among the precious metals and gemstones, gold, PGE (Platinum Group Elements), and diamonds, respectively [25-27]. A scarcely to non-vegetated system of alluvial fans debouching into a periodically flooded more or less straight drainage system is displayed in Figure 4a. They often coalesce resulting in an apron of bajada fans in the foreland of rising modern fold belts such as the Andes in Argentina (Figure 4a). It is a sort of continental terrigenous sediments that has been extensively discussed by [28] and Galloway et al. [29]. Moving downslope the drainage systems change from braided, through meandering into anastomosing fluvial drainage system reflecting a decreasing gradient (Figure $4 \mathrm{~b}-\mathrm{d}$ ). There are heavy minerals found in all zones of the alluvial-fluvial drainage system, yet the probability of finding economic placer deposits of gemstones wanes downstream, as indicated by arrowhead facing downward (Figure $4 \mathrm{~b}-\mathrm{d}$ ). The potential to find gemstone-bearing placer deposits is high in sand and gravel bars of the braided streams as shown by the finds of tourmaline and garnet in the tributaries of Trisuli River in the Ganesh Himal, Nepal (Figure 4e). Meandering rivers, following more downstream, only host heavies in bar sands of the active channels of the drainage system, whereas oxbow lakes indicative of abandoned drainage systems are barren as is also the case with anastomosing fluvial systems, which are rife with suspended load as a consequence of the lower flow regime (Figure 4c). Black sands or fluvial placer deposits are frequently abundant in mafic minerals and magnetite so as to accentuate the textures of the cross-bedding and enabling the exploration geologists in the field to determine the flow regime, flow direction, and accretion, and last but not least, the siting of gemstone concentrations. These black sands, although subeconomic are cast into the role of "pathfinders". Within the channel heavy minerals (such as gold and diamonds) used to be preferentially laid down in the channel lag deposits of braided streams immediately overlying the bedrock (Figure $4 \mathrm{~g}$, Section 3.8). 


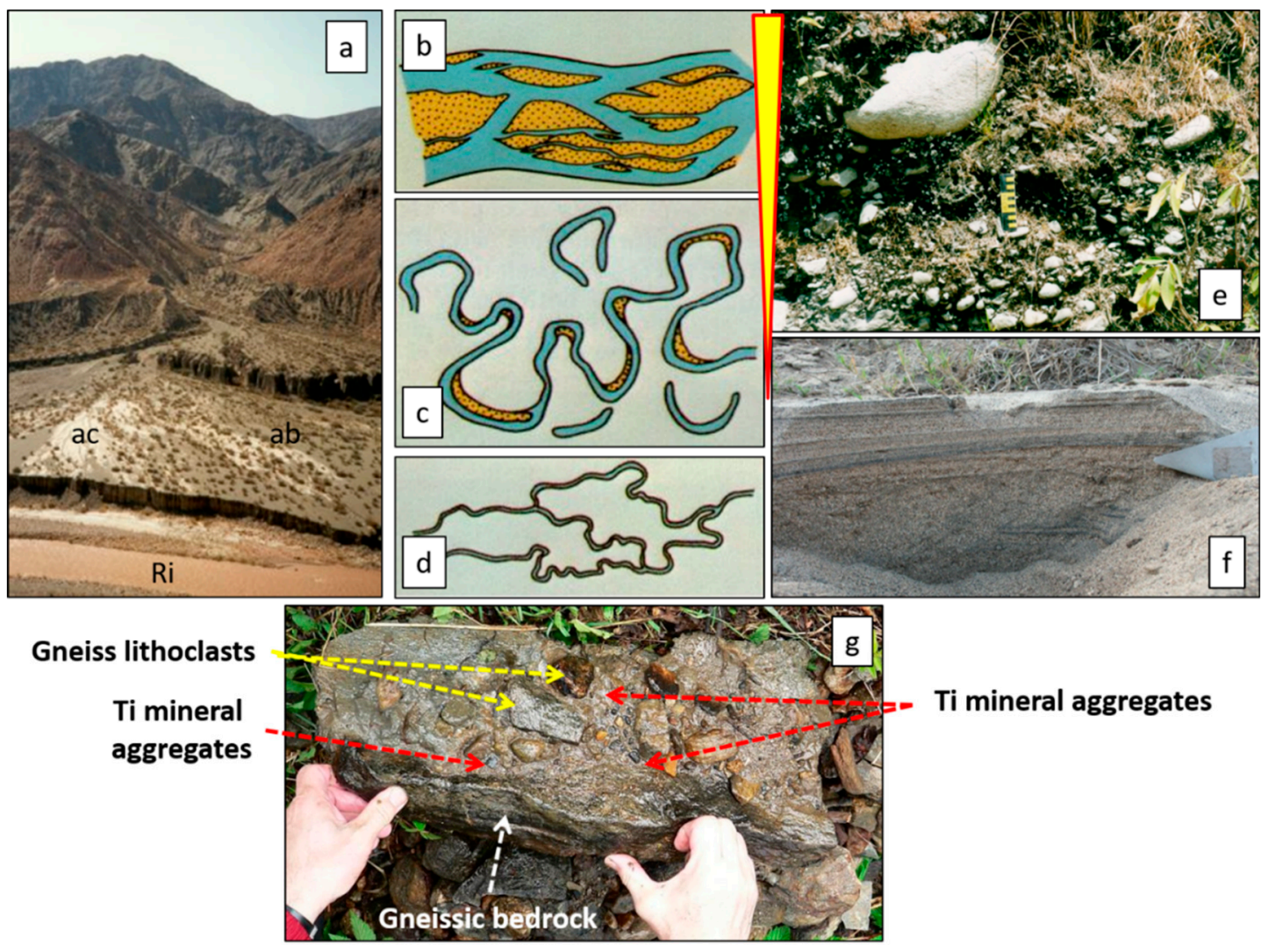

Figure 4. Alluvial-fluvial placers. (a) Scarcely to non-vegetated alluvial fans debouching into a periodically flooded more or less straight drainage system. The basement rocks are PermoCarboniferous in age, the fan system has been developing since the Pleistocene (San Juan Valley, Argentina). Ri: active braided trunk river system, ac: active channels, and ab: abandoned channels. There are at least two stages of fan evolution. (b) Braided river system with the sandy bars in yellow. (c) Meandering river system with the sandy bars in yellow. Sand bars developed in the active channels at the point bars of the meander bows while the oxbow lakes and abandoned isolated meander belts filled with fine-grained clastic and organic sediment. (d) Anastomosing river system with almost no sand bars. The vertical wedge-shaped pattern denotes a decreasing-downstream concentration of heavy minerals by alluvial-fluvial processes. (e) Active channel system in the Ganesh Himal, Nepal, with rounded mega-clasts at the boundary between alluvial fans and braided rivers. Imbrication denotes flow direction from left to right. It is the environment most prospective for gemstone placers (in this tourmaline and garnet). (f) Black sands (fluvial placers of pyroxene and magnetite) underscore the sedimentary bedding textures in a tributary of the Shire River, Malawi. Sands with distorted bedding in a whirlpool overlain by sands characterized by antidunes. (g) Channel lag deposits forming the lowermost concentration of heavy minerals and aggregated immediately on top of the bedrock of the braided streams (Pleystein, SE Germany). In this case the fluvial placer is composed mainly of "nigrine" (rutile-ilmenite intergrowth).

\subsubsection{Deltaic Placers}

Fluvial drainage systems end up in the sea or in large depressions on land occupied by perennial or ephemeral lakes. Depending upon the three forces operative in these aquatic environments a tripartite subdivision into fluvial-, wave-, and tide-dominated deltas can be achieved for these point-source landforms (Figure 5). As can be deduced from the triplot only mixed-type wave- and fluvial-dominated deltas provide favorable conditions to emplace deltaic placer deposits, because these peculiar placer types benefit from the balanced interaction of rivers, responsible for a continuous supply of detritus from the hinterland, and waves which act as a "natural processing plant". By the back and fro and the longshore drift of the waves the "wheat is separated from the chaff". Irrespective of the final 
depocenter, there are fluvio-deltaic placers along the shoreline of lakes such as at the Zr-Ti-REE placers of Salimaat Lake Malawi and the placers in the Sulina paleo-delta of the River Danube which evolved from a regression as early as 4000 years ago [12,30]. Apart from the ilmenite, magnetite, chromite, zircon, titanite, staurolite, kyanite, apatite, pyroxene, amphibole, and apatite they also host garnet and tourmaline, yet not of gem quality. The tidal-dominated deltas or estuaries are undernourished with regard to the sediment supply from land and characterized by prevailing fine-grained siliciclastics over course-grained particles and miss natural panning processes that could lead to a concentration of heavy minerals. Excluding the sediment-hosted diamond (Section 3.8) and precious corundum deposits (Section 3.7), deltaic placers play a subordinate role in the accumulation of gemstones.

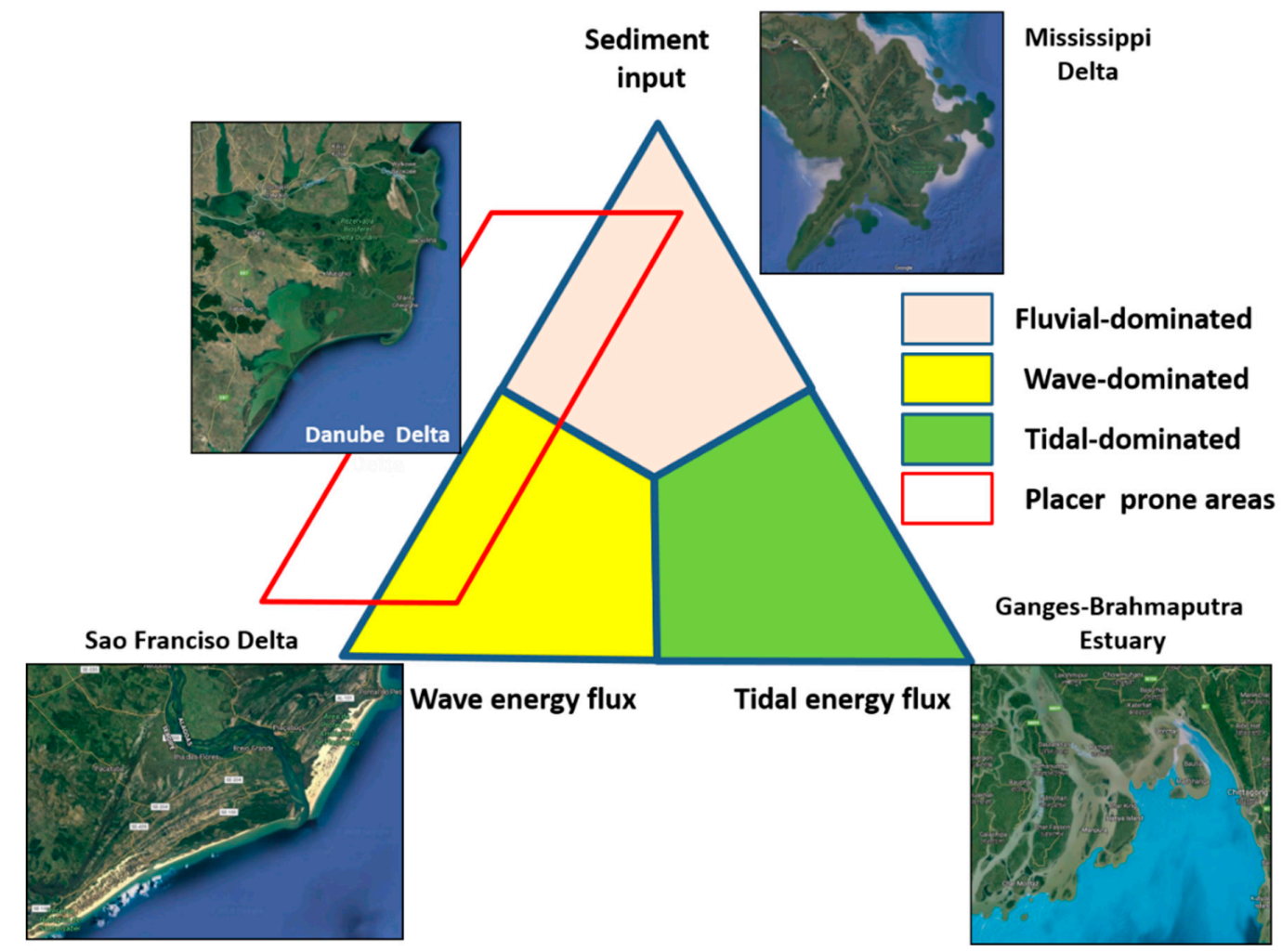

Figure 5. Deltaic placer deposits (area framed by the red line) as a function of wave energy flux, tidal energy flux and sediment supply. Satellite images (source: Google Maps) have been introduced to show the various landform of wave, tidal, and fluvial-dominated deltas. The mixed fluvial to wave-dominated delta of the River Danube has been selected as reference type for mixed-type wave-fluvial-dominated deltaic placer deposits because of its widespread heavy mineral concentration, among others garnet and tourmaline.

\subsubsection{Nearshore Marine and Aeolian Placers}

The most distal placer deposits relative to the source of minerals are located along the terrigenous shorelines of the sea or large inland lakes where they take advantage of the point-source landforms described in Section 2.2.4 as detrital inlets (Figure 1). The concentration of heavy minerals is accomplished by the wave action in the breaker, surf, and swash zones and by wind in the subaerial zone landward of the three zones called the backshore (Figure 6). The various sedimentological processes and the geomorphological features of this peculiar environment between land and sea are very complex and were dealt with in some comprehensive papers covering the entire tidal range from the micro- to the macrotidal hydrodynamic regimes [31-36]. Concluding from Figure 5, tidal dominated environments, whether it is a point source or linear shoreline environment, are less favorable areas to produce placer deposits. The mechanism shaping the coast in a regressive mixed energy barrier islands 
has been named as "drumstick model" [36] (Figure 6a). Figure 6a depicts the wave action and how the clastic material is transported from a source area to the depocenter by longshore currents, a process that is very productive, as shown by the zone of accretion in the oblique aerial view of Capitain Sam's inlet, CA, USA (Figure 6b). Near the high-water line of the backshore environment at Kiawah Island, CA, USA, ilmenite placers in coastal antidunes structures evolved (Figure 6c). These bedforms can also occur in fluvial environments given the Froud number exceeds 1 attesting to an upper or supercritical flow regime. The bedforms bearing placer minerals move upstream in the opposite direction of those bedforms of the lower flow regime used to do (Fielding 2006) [37].

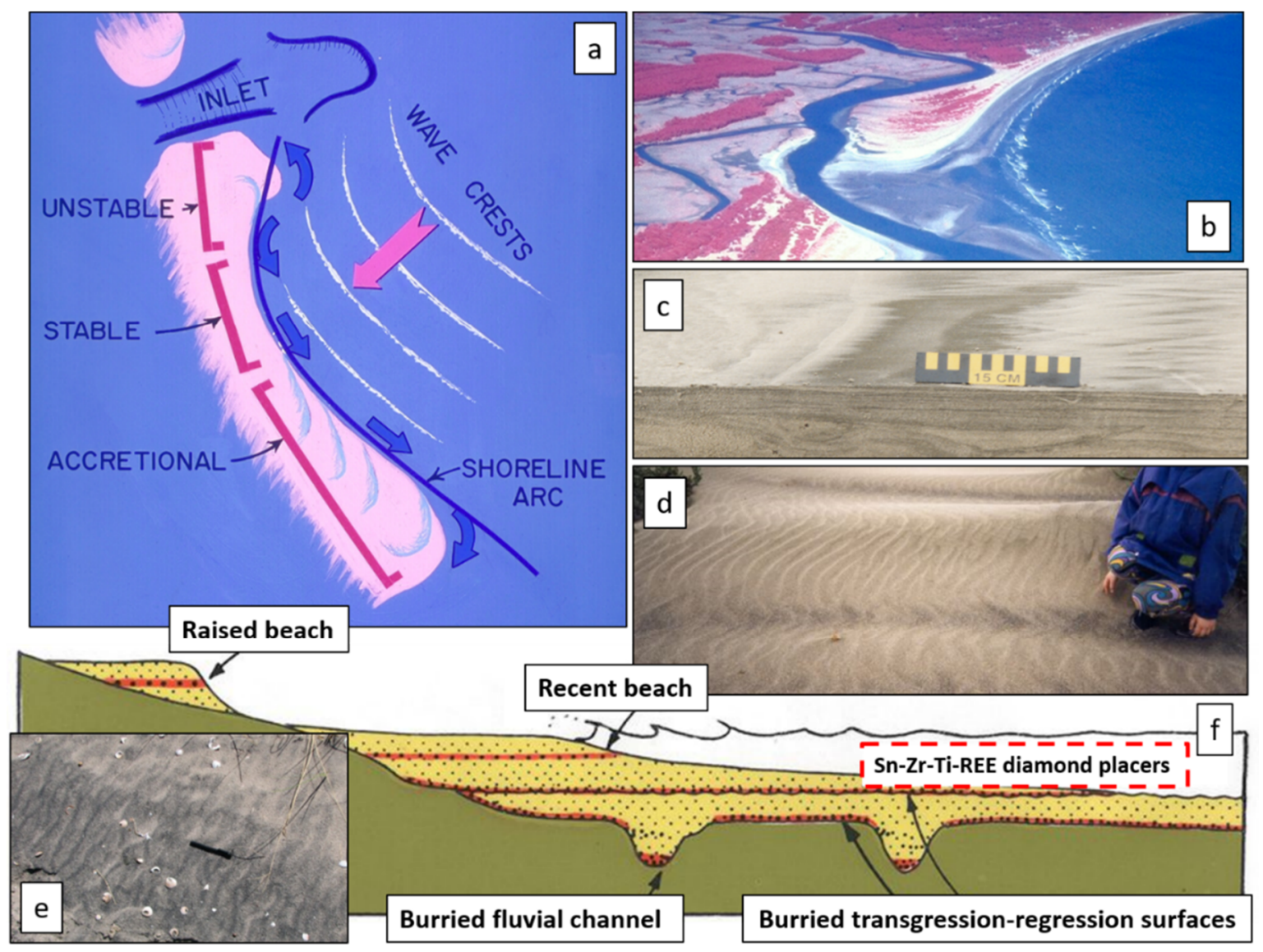

Figure 6. Nearshore marine and aeolian placers. (a) The linear barrier island shoreline configuration by M.O. Hayes illustrating the motion of waves and the sediment transport from the unstable zone to the zone of accretion. (b) Oblique aerial view of Capitain Sam's inlet. The inlet migrates towards the $S$ (bottom of photograph at a rate of 60 to $70 \mathrm{~m}$ per year) (photograph: courtesy of M.O. Hayes). (c) Ilmenite placers in coastal antidunes near the high-water line of the backshore environment at Kiawah Island, CA, USA. Arrowhead points towards the sea. (d) Sigmoidal-crested sand dunes with bifurcation at Lanzarote Island, Spain, with aeolian placers of magnetite and mafic minerals. (e) Two different types of heavy mineral accumulations. First generation heavy mineral accumulation produced during storms resulting in shoreline-parallel layers at the boundary between the dunes and the backshore (see for scale black biro $-8 \mathrm{~cm}$-parallel to the shoreline). Second generation heavy mineral redeposition in bifurcating asymmetrical ripples as a consequence of wind and water parallel to the shoreline in NE Patagonia, Argentina. (f) Cartoon to show the association of buried fluvial placers and beach placers of different generations [38].

When aquatic placers get exposed, be it in a coastal or fluvial environment (e.g., flood plain deposits) and brought into the reaches of strong winds sigmoidal-crested sand dunes and dune belts come into existence with another accumulation of heavy minerals (Figure 6d). An example is the coast in NE Patagonia, Argentina, which shows a 1st generation heavy mineral accumulation 
produced during storms resulting in shoreline-parallel layers at the boundary between the dunes and the backshore and a 2nd generation heavy mineral redeposition in bifurcating asymmetrical ripples as a consequence of wind and water parallel to the shoreline (Figure 6e). An idealistic way of placer deposition and redeposition in a composite fluvial and coastal marine environment was described by Evans [38]. Fluvial placers in drowned river valleys are the source for marine placers reworked along transgressive surfaces.

After being raised above the sea level and exposed to wind, deflation may provoke another type of aeolian placers to come into being in the backshore zone. Aeolian placers are the result of one of the three major driving forces (fluvial, marine, and aeolian) in the concentration processes of diamonds in Namibia (Section 3.8). Aeolian processes come into effect as deflation and accumulation. In a dry climate loose and fine particles are lifted up and transported away, leaving behind lag deposits of heavier components which characterize the hamadah or serir desert among the arid landforms, which are equivalent to the eluvial placers. Transportation and deposition of heavy minerals generate aeolian dunes denominated based on their shape and orientation as seif, parabolic, barchan, and transverse dunes or dune belts/beach ridges in the coastal environment (Figure 6c,e)—see Section 3.8 for diamonds.

\subsection{The Physical-Chemical Regime of Gemstone Placer Deposits}

\subsubsection{Physical Parameters}

Placer deposits are mechanical deposits which are formed at the interface between the lithosphere (parent rocks) and atmosphere (controlling through the climate weathering and the intensity of the transporting agents water, ice and wind) resulting in the shaping of the landscape and delivery of minerals and lithoclasts. The main transport medium is water, the flow regime of which can be subdivided into a low-energy system encompassing prevalently suspended-load relevant for the formation of clay deposits and a high-energy system characterized by bedload mineral assemblages, among others, those containing gemstones. Depending upon the aridity or humidity of the climate zone hosting the placer deposit, the river discharge and bedload is either higher or lower.

With the exception of the dry continental and the tropical arid climate zones extending parallel to the equator on the Northern and Southern hemisphere, all remaining morphoclimatic zones provide favorable conditions to develop aquatic placer deposits, while the dry continental environments are prone to aeolian placers [39].

It is the ambient influences that control the settling and the accumulation of the heavy minerals. The internal factors controlling the emplacement of placer deposits are the grain morphology and second to none the density of the minerals. Two process hydraulic sorting and entrainment have a strong say on how, where, and when heavy minerals are laid down along the thalweg and by the coastal marine currents [40-42]. Figure 7 illustrates the hydraulic equivalence of some opaque heavy minerals in common placer deposits relative to quartz [41]. It shows the spheres of the selected opaque minerals supplemented with gemstones in the density interval $2.8 \mathrm{~kg} / \mathrm{m}^{3}$ (beryl) to $4.7 \mathrm{~kg} / \mathrm{m}^{3}$ (zircon), which have the hydraulic settling equivalence of quartz or in other words, identical settling velocity unit (Table 1). It was far earlier recognized that hydraulic settling of heavy minerals is not the only way of concentration in the fluvial and coastal marine environments. Considering the entrainment equivalence of placer minerals or interstice trapping in placer formation, the average median size of magnetite-ilmenite comes much closer to the size of a reference quartz grain than considering the hydraulic equivalence of grains only. 


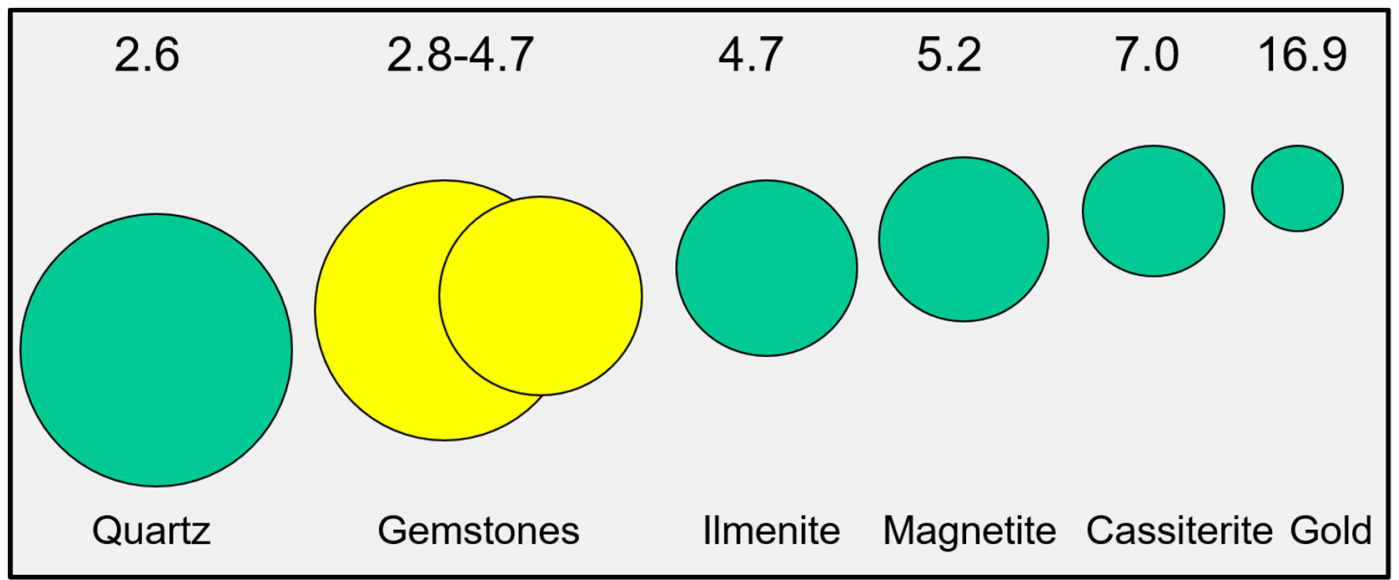

Figure 7. Hydraulic equivalence of heavy minerals relative to quartz (source of data, excluding those of gemstones from Reid and Frostick 1985) [41] with an amendment by the author with regard to gemstones.

\subsubsection{Chemical Parameters}

The chemical composition and the crystal structure, including cleavage and fractures of the gem minerals, are crucial when it comes to an assessment of the vulnerability to attrition and resistance to chemical weathering (e.g., silicates and phosphates bearing bivalent Fe are very much susceptible to oxidation) of placer minerals in the source area as well as along the thalweg on transport (Figure 8). There are several comprehensive studies by Morton and Lång $[43,44]$ addressing the resistance of the common rock-forming minerals to weathering, which have been amended by Dill [45-47] as to the weathering of clay minerals and some rare minerals from pegmatitic and ultrabasic source rocks. The length of the horizontal bar in Figure 8 reflects the relative stability of the gemstones, but does not necessarily correlate with the type of placer deposits or distance from their source rocks. Olivine is the least resistant transparent rock-forming mineral and its $\mathrm{Mg}$-enriched member is almost exclusively found in very young placers near the source rock. It can be of colluvial, fluvial, and coastal marine type; only the proximity to the source rocks counts as shown by the "Green Beaches" at Papakolea Beach, Hawai-USA where the waves directly cut into the volcaniclastic host rock of olivine. The Fe-enriched end members of this s.s.s. are very rare, but locally, are strongly enriched in stream sediments forming some sort of a fluvial placer. It is the most recent type of placer and is only found next to ancient smelters where fayalite was washed out from dumped Fe slags. This example was selected to raise awareness among exploration geologists of the wide range of artificial chemical compounds in modern stream sediments that have been derived from production sites and may make false claims by simulating gemmy material [48]. 


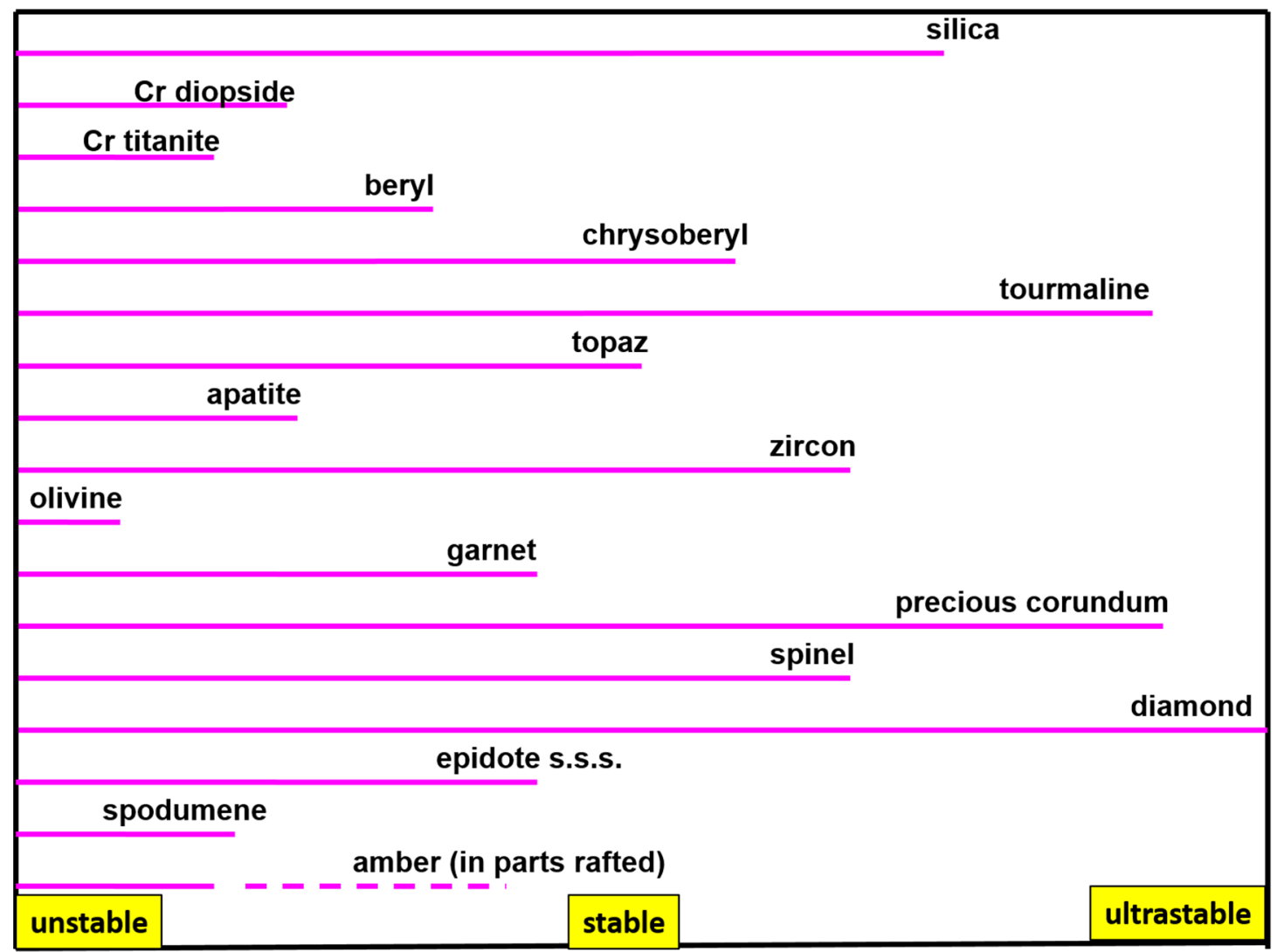

Figure 8. Relative stability of gemstones in placer deposits against attrition and weathering (data from (Morton and Dill [43,45-47])).

\section{Gemstone Placers from Beryl to Zircon}

The platform for a more detailed discussion of gemstones in placer deposits and their integration into the overall classification scheme of magmatic, structurebound, sedimentary, and metamorphic mineral deposits is the "Chessboard" classification scheme of mineral deposits: Mineralogy and geology from aluminum to zirconium", which was supplemented by a series of digital maps with a description of each gemstone group. All known gemstone groups worldwide were treated by country, geology, and geomorphology on 99 digital maps [1,49]—see Appendix A. For the current placer-type deposits the distribution of gemstone deposits the reader is referred to the geomorphological maps as the most relevant tool to get an insight into the enrichment of gemstones worldwide. Notwithstanding the common practice of dealing gemstones corresponding to their economic assessment, in the current review, the prevailing elements or chemical compounds are used for classification.

\subsection{Beryllium-Bearing Gemstone Placers-Beryl and Chrysoberyl}

There are several Be minerals that can be ranked among the gemstones such as euclase, phenakite and taaffeite, but only the true heavy mineral chrysoberyl and the modifications of transparent precious beryl (aquamarine/blue, morganite/pink, heliodor/yellow, emerald/green, goshenite/colorless, and pezzottaite/raspberry-red) are attractive for jewelers and mineral dealers [50-59]. The various varieties of precious beryl, although not a heavy mineral in the strict sense occur in alluvial (fluvial) placers and residual placers close to sites where the primary deposits are exposed to weathering and denudation (Figure 9a-c). Beryl can under intensive tropical chemical weathering also decompose into kaolinite-group phyllosilicates. A typical primary-secondary association of beryl gemstones is the side-by-side of pegmatite hosted aquamarine and alluvial placer-hosted aquamarine, e.g., Teofilo Otoni, Brazil. 

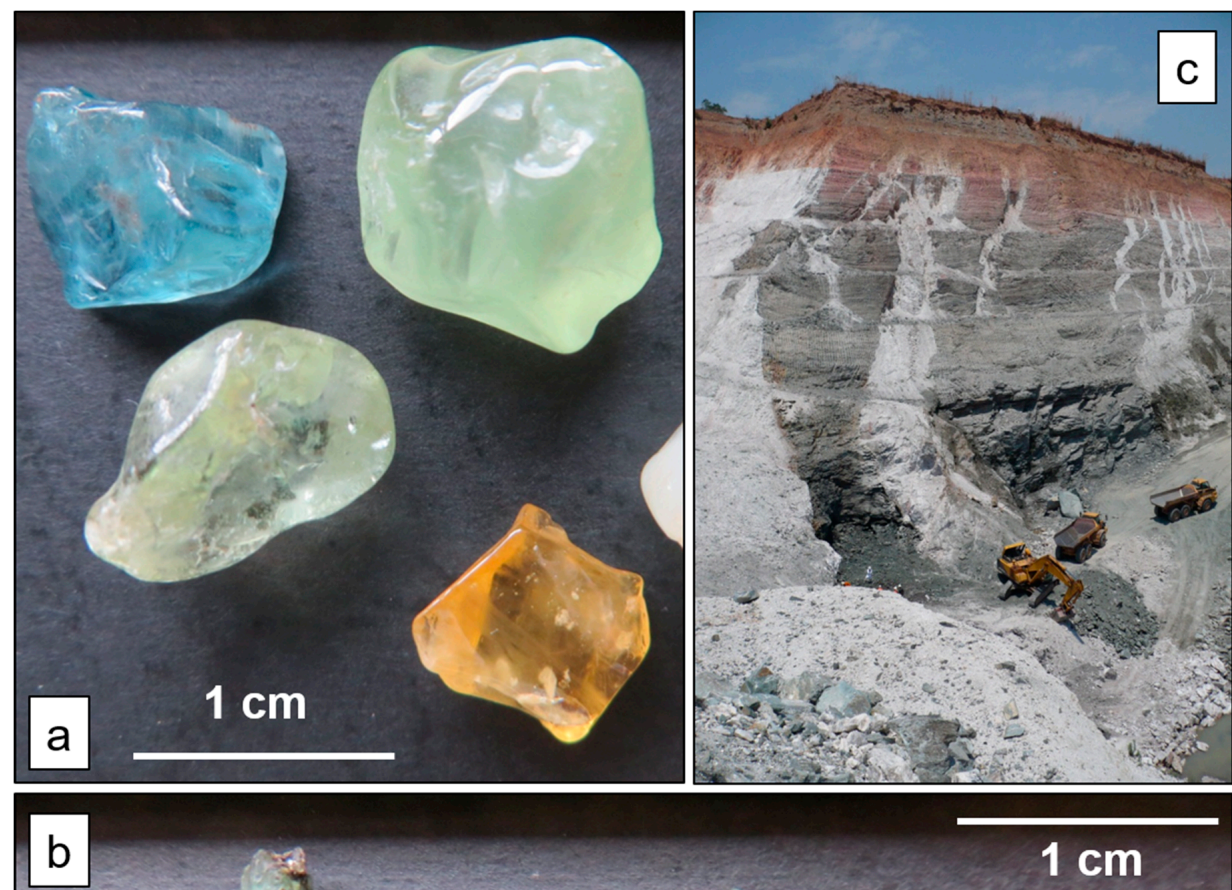

b
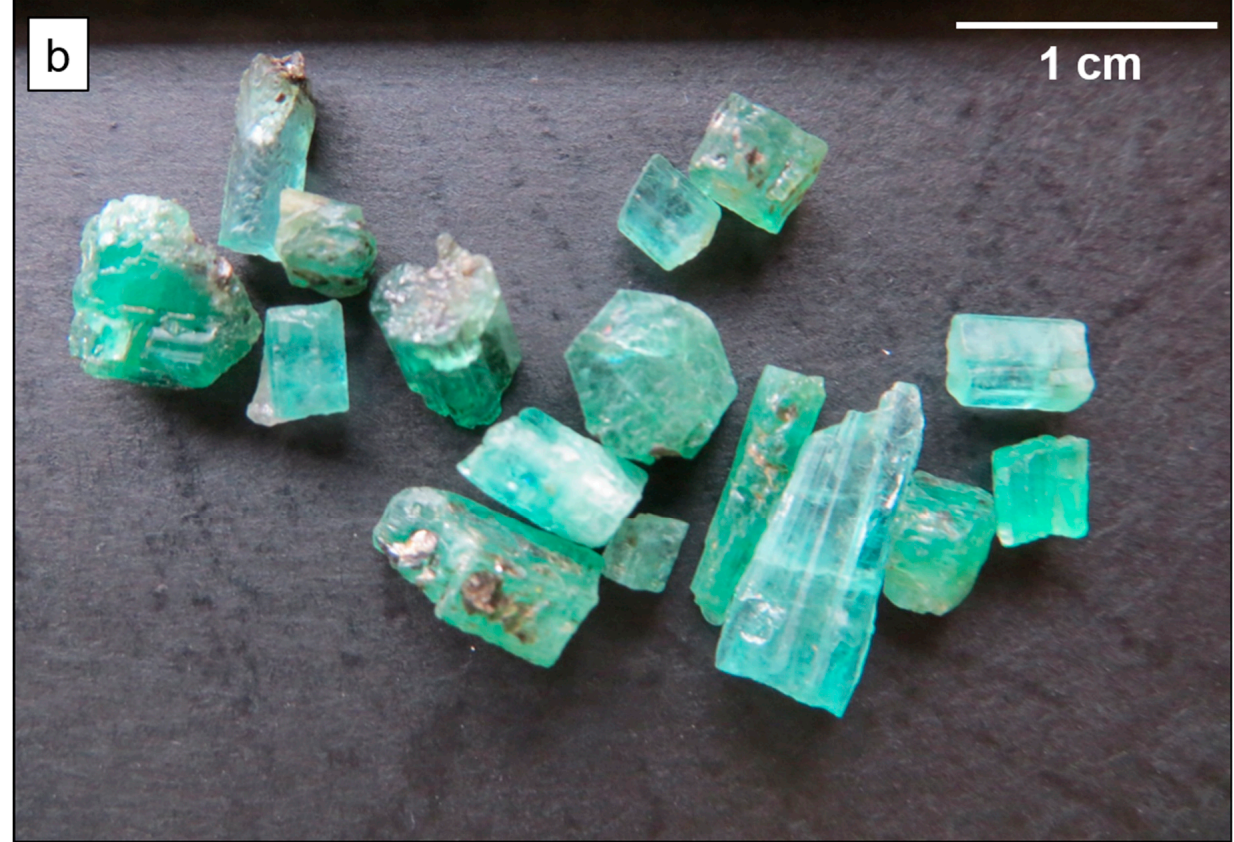

Figure 9. Varieties of beryl from different placer deposits. (a) Aquamarine and multicolored beryl from alluvial (fluvial) deposits in Tanzania. (b) Emerald fragments at the most proximal site to the current open pit. (c) Schist-hosted pegmatite related emerald deposit in Zambia. The chlorite-talc schists (metabasic rocks are overlain by muscovite-biotite schists. The emerald deposit gradually passes into the regolith forming the topstratum (residual placer) (Photograph: T. Häger).

Chrysoberyl is also exploited from alluvial-fluvial placer deposits, e.g., in Sri Lanka and in Brazil [60]. In some mining districts, the gemstones form a by-product of alluvial gold exploration and exploitation. From this secondary placer accumulation in gravels the diggers moved along the thalweg upstream and found their way to the primary deposits, mostly pegmatites [61]. The pits were opened up in alluvial-fluvial placers and the most favorable layers encountered approximately three meters under the valley floor in clay and sand [62]. It is the channel lag deposits that developed immediately on top of the discontinuity between the drainage system and the bedrock leading to the zone to be targeted upon with the most success. Proctor [63] described colluvial-alluvial gem gravels, termed by the locals "cascalhos" which alternate with different layers of red, gray and black 
clay, and sand. Chrysoberyl, which is the gemstone of interest is associated with beryl (heliodor, aquamarine), topaz, rhodolite garnet, andalusite, and also mixed up with considerable amounts of quartz and olivine. In another alluvial-colluvial placer alexandrite was recovered which originated from a pervasively kaolinized weathering mantle. Chrysoberyl is also known as a minor constituent from placer deposits operated for precious corundum such as the New England Gem Fields in New South Wales, Australia [64].

\subsection{Boron-Bearing Gemstone Placers-Tourmaline}

Tourmaline s.s.s. are among the most widespread heavy minerals owing to the strong resistance to all kinds of alteration and they are besides zircon and rutile ubiquitous in clastic sedimentary rocks, but tourmaline of jewelry quality is rarely mined from placer deposits, excluding some sites in Sri Lanka, Brazil, and Nepal [65-68]. The rugged terrain favors the concentration of these gemstones in dislodged blocks scattered in colluvial deposits and grade downstream in alluvial (fluvial) drainage systems (Figure 3b). Basset (1987) [69] provided a good overview of these occurrences. Multihued elbaite is known from Hyakule and Phakuwa in Eastern Nepal. Further information on Nepalese gemstones has been published by UN-ESCAP, Aryal, and Kaphle et al. [70-72]. High mountainous areas are promising target areas to harness gravity driven mass wasting processes shaping the landscape for placer exploitation. Tourmaline s.s.s is present in the entire chain of placer deposits from the residual through to the marine placer deposits (Figure 10a,b). The rare colorful varieties of elbaite called indicolite (blue), rubellite (red), verdellite (green), and the most precious blue one called Paraiba Tourmaline are frequently exploited from primary pegmatitic deposits [61] excluding the peculiar highly reliefed terrains (Figure 10c-e). Owing to its outstanding stability, panned concentrates of tourmaline can be used as pathfinder minerals. Multicolored concentrates like those from Tanzania (Figure 10a) are positive indicators, whereas monotonous tourmaline heavy mineral suites composed of elbaite-schorl series or dravite-schorl series sensu Henry et al. [73] only like those met in SE Germany do not signal a high potential of finding precious tourmaline in the catchment area and in the source rocks around (Figure 10b). Apart from tourmaline there are numerous B-bearing minerals some of which may also achieve gemstone quality (Table 2). Studies of these B-bearing gem minerals are only focused on their primary deposits so that any integration into a review like that devoted to their secondary deposits is fraught with difficulties.

Table 2. Boron-bearing minerals, achieving locally, gem quality [1].

\begin{tabular}{cc}
\hline Axinite & $\mathrm{Ca}_{2} \mathrm{MgAl}_{2}\left(\mathrm{BO}_{3}\right) \mathrm{Si}_{4} \mathrm{O}_{12}(\mathrm{OH})$ \\
\hline Danburite & $\mathrm{CaB}_{2} \mathrm{Si}_{2} \mathrm{O}_{8}$ \\
\hline Datolite & $\mathrm{CaB}\left(\mathrm{SiO}_{4}\right)(\mathrm{OH})$ \\
\hline Dravite & $\mathrm{NaMg}_{3} \mathrm{Al}_{6}\left(\mathrm{BO}_{3}\right)_{3} \mathrm{Si}_{6} \mathrm{O}_{18}(\mathrm{OH})_{4}$ \\
\hline Dumortierite & $\mathrm{Al}_{6.9}\left(\mathrm{BO}_{3}\right)\left(\mathrm{SiO}_{4}\right)_{3} \mathrm{O}_{2.5}(\mathrm{OH})_{0.5}$ \\
\hline Elbaite & $\mathrm{NaLi}_{2.5} \mathrm{Al}_{6.5}\left(\mathrm{BO}_{3}\right)_{3} \mathrm{Si}_{6} \mathrm{O}_{18}(\mathrm{OH})_{4}$ \\
\hline Elbaite (Paraiba) & $\mathrm{Na}\left(\mathrm{Li}_{,} \mathrm{Al}_{3} \mathrm{Al}_{6}\left(\mathrm{BO}_{3}\right)_{3} \mathrm{Si}_{6} \mathrm{O}_{18}(\mathrm{OH})_{4}\right.$ \\
\hline Elbaite (Indicolite) & $\mathrm{Al}_{6} \mathrm{~B}_{5} \mathrm{O}_{15} \mathrm{~F}_{2.5}\left(\mathrm{OH}_{0.5}\right.$ \\
\hline Jeremejevite & $\mathrm{Mg}_{3.5} \mathrm{Fe}^{2+}{ }_{0.2} \mathrm{Al}_{5.7}\left(\mathrm{SiO}_{4}\right)_{3.7}\left(\mathrm{BO}_{4}\right)_{0.3} \mathrm{O}_{1.2}(\mathrm{OH})$ \\
\hline Kornerupine & $\mathrm{Ca}_{0.77} \mathrm{Na}_{0.19} \mathrm{Al}_{8.8} \mathrm{Ti}_{0.19} \mathrm{Cr}_{0.03} \mathrm{Zr}_{0.04} \mathrm{~B}_{1.06} \mathrm{O}_{18}$ \\
\hline Painite & $\mathrm{Na}\left(\mathrm{Li}_{1} \mathrm{Al}_{3} \mathrm{Al}_{6}\left(\mathrm{BO}_{3}\right)_{3} \mathrm{Si}_{6} \mathrm{O}_{18}(\mathrm{OH})_{4}\right.$ \\
\hline Elbaite (Rubellite) & $\mathrm{Ca}_{2} \mathrm{Mg}_{4.5} \mathrm{Al}_{1.5} \mathrm{Si}_{3.6} \mathrm{Al}_{1.8} \mathrm{~B}_{0 .}$ \\
\hline Serendibite & $\mathrm{MgAl}_{\left(\mathrm{BO}_{4}\right)}$ \\
\hline Sinhalite &
\end{tabular}




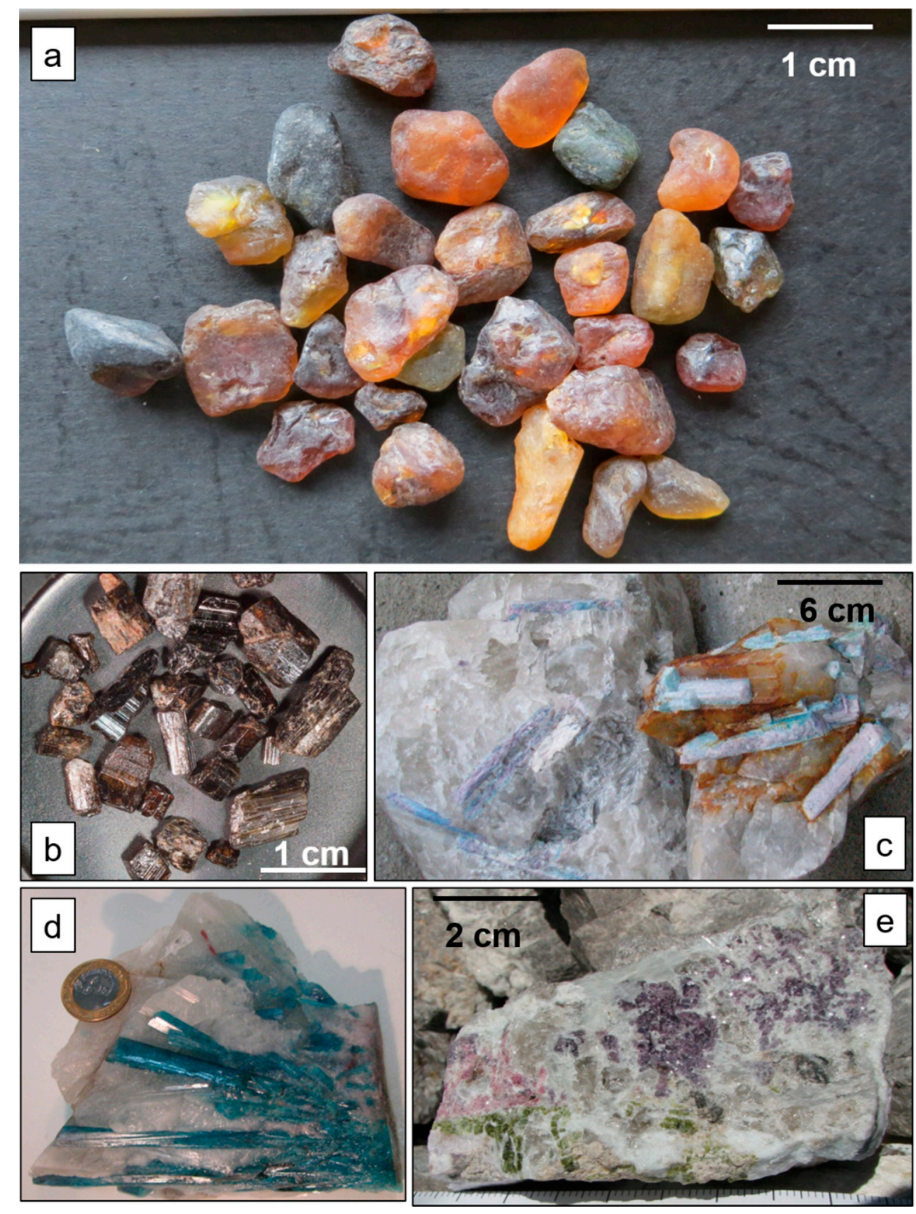

Figure 10. Tourmaline s.s.s. from placer and pegmatite deposits. (a) Panned concentrate for subrounded tourmaline from a fluvial placer in Tanzania. (b) Tourmaline concentrate from a colluvial placer SE Germany. (c) Pink and blue elbaite tourmaline laths in the Batalha Pegmatite, Brazil. (d) Paraiba tourmaline from the Capoeira Pegmatite, Brazil. (e) Pink and blue and elbaite and green verdellite from the Mendoza Pegmatite Province, Argentina.

\subsection{Fluorine-Bearing Gemstone Placers-Topaz}

Topaz accommodates as much as $11 \mathrm{wt} \% \mathrm{~F}$ in its lattice and falls short of fluorite as a source of $\mathrm{F}$, the most common ore mineral mined for fluorine ( $48.67 \mathrm{wt} \% \mathrm{~F}$ ). It is dealt with here as the only relevant F-bearing gemstones found in placer deposits. Topaz and tourmaline are common associates in highly-differentiated granites and are also found in some rare-element pegmatites $[1,61,74]$. They accompany cassiterite and wolframite in granite-related Sn-W deposits. Seldom has such well-crystallized topaz appeared elsewhere as in the mineral aggregates of Thomas Range, Utah, USA (Figure 11a). Topaz takes an intermediate position as to the mineral stability and its grains swiftly see their edge beveled and grinded to a grain size neither of relevance for jewelers nor for exploration geologists who might make use of them as pathfinder to primary gemstone or ore deposits (Figures 8 and 11b). Topaz is a heavy mineral common in the clastic dispersion halo around highly differentiated granites, but at around four-to-five $\mathrm{km}$, it disappears from the heavy mineral assemblage of stream sediments and looses its role as a pathfinder mineral to $\mathrm{Sn}-\mathrm{W}$ deposits. Eluvial placer deposits in Brazil and alluvial-(fluvial) placer deposits in Brazil, USA, Sri Lanka and Australia are the mayor sedimentary sites to recover topaz from. Topazes from Ouru Preto, Brazil, are washed out of a thick lateritic saprolite, a gentle method to save the most precious specimens of their kind. Fluorite, although a member of the group of heavy minerals, rarely shows up in stream sediments, and owing to its perfect cleavage, it is met only as tiny splinters without any value. 


\subsection{Phosphate-Bearing Gemstone Placers-Apatite-Group Minerals}

Apatite of gem quality is rare, even if this phosphate shows up in a great variety of colors (Figure 12a). It is less attractive for gem dealers than for mineral collectors who put facetted specimens on display in their showcase. It is a common phosphate mineral in sedimentary, metamorphic and magmatic rocks, and therefore, ranks among the most widespread heavy minerals, although its stability is moderately high, particularly under the attack of acidic meteoric solutions during weathering (Figure 8). In residual deposits originating from long-term pervasive chemical weathering it has a low conservation potential and gets decomposed to almost full completeness in the topmost saprolite [33,34]. The phosphates newly formed in the course of supergene alteration are part of the APS minerals (aluminum-phosphate-sulfate minerals) when the $\mathrm{pH}$ significantly drops below seven. Dependent on the soluble compounds associated with $\mathrm{Al}$ and $\mathrm{P}$ in the meteoric solutions different APS minerals come into existence, such as turquoise which may develop in meteoric fluids abundant in $\mathrm{Cu}$ [75]. They pertain to a wide range of supergene gemstones categorized as duricrusts, or in the current example, termed as apicretes or phoscretes. If at all present in placers, these chemical sediments only occur in stream sediments proximal to the site of formation.
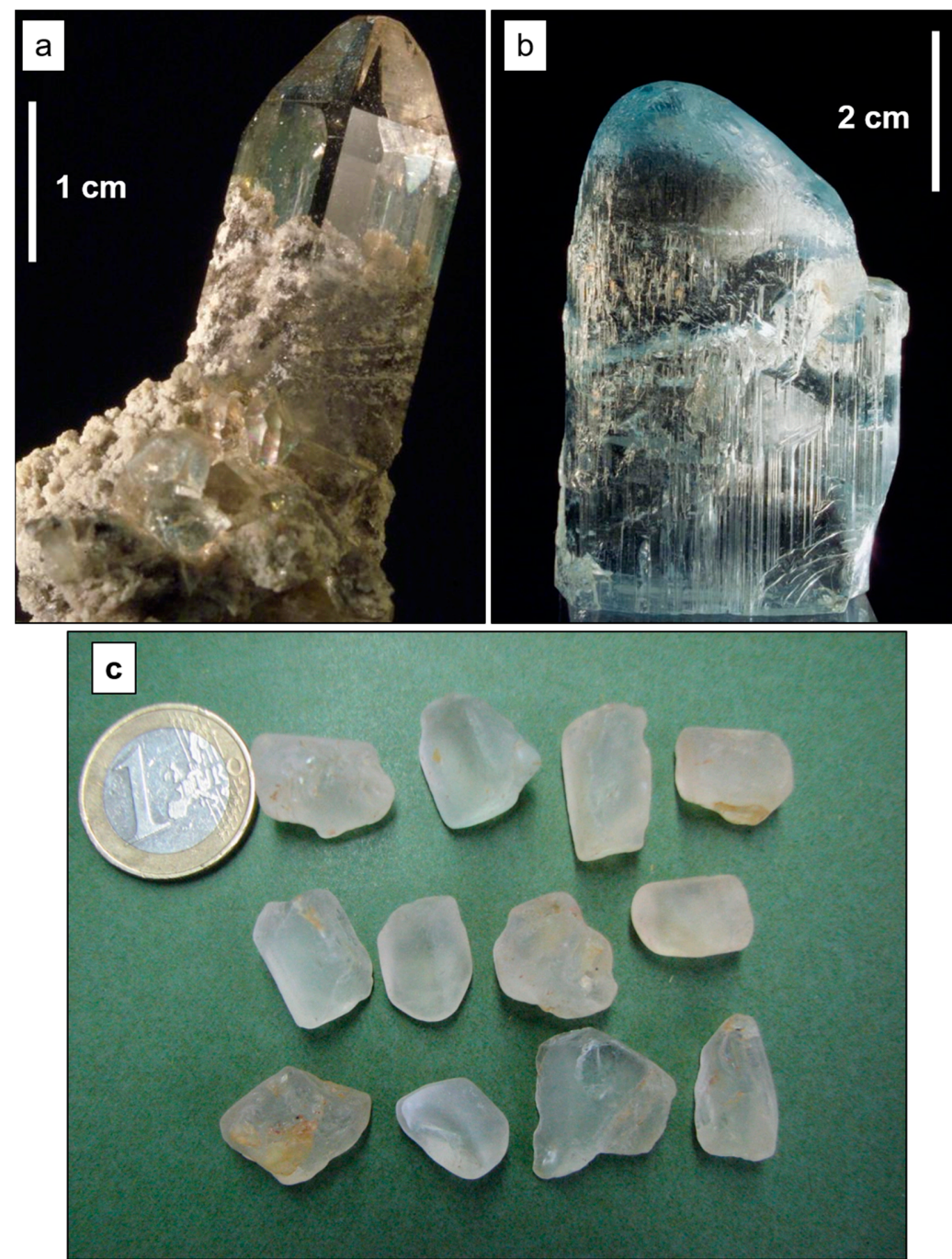

Figure 11. Topaz crystals—-from the primary deposit to the secondary deposit in placers. (a) Euhedral well-crystallized transparent topaz from Thomas Range, Utah, USA. (b) Subhedral crystal with beveled edges, Brazil. (c) Anhedral detrital topaz from eluvial placer deposits in the Rondonia tin mining district, Brazil. 

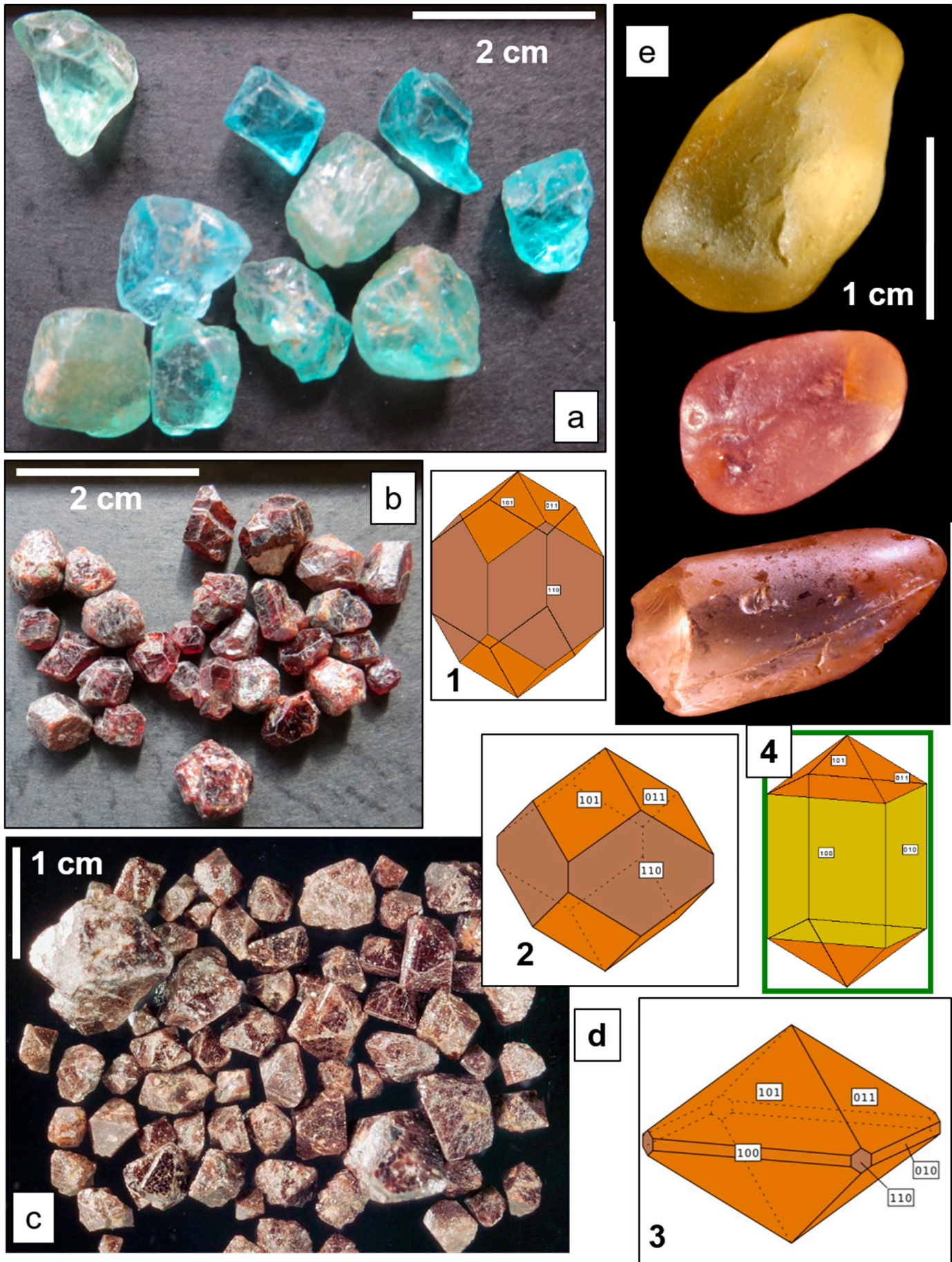

Figure 12. Apatite and zircon from placer deposits. (a) Greenish and blue apatite from alluvial placer deposits in Madagascar. (b) Brownish red translucent zircon from alluvial placer deposits in Madagascar. (c) Brown opaque zircon from alluvial placer deposits in SE Germany. (d) Crystal morphologies typical of zircon from pegmatitic deposits (1-3) and from their country rocks (4). (e) Pinkish and yellow well rounded zircon grains from an alluvial placer in SE Germany (photograph: B. Weber).

Two processes, tectonic uplift and unroofing, controlled the variation of heavy minerals (Dill 1995) [76]. When the relief is low, the chemical weathering intensive and the erosion is slow meteoric fluids can attack these minerals for a long period of time and thus eradicate heavy minerals of low stability as is the case with apatite. To provoke apatite to show up in the alluvial fans and its placers 
the uplift must be accelerated so that the evolution of a full-blown weathering profile is impeded [76]. Given there are source rocks such as pegmatites fostering the growth of mega-crystal exposed in the hinterland apatite are likely to be part of alluvial placer deposits at a considerable size (Figure 12a). The majority of apatite, however, is observed in the sand fraction of various placers and only of stratigraphic value.

\subsection{Zirconium-Bearing Gemstone Placers-Zircon}

In contrast to the aforementioned phosphate mineral apatite, zircon takes quite a different position in the stability diagram of Figure 8, being placed near the ultra-stable contenders. In combination with its ubiquity in the metamorphic and magmatic rocks, it is second to none among the heavy minerals. Together with rutile, ilmenite, and "leucoxene", zircon forms the major constituents of the marine placer deposits mined along the coast of Australia, Canada, South Africa, India, and USA, which constitute the sole economic source of zircon of industrial grade $[3,11,13,17,77,78]$. Its grain size in these depositional environments is far too small to attract the attention of jewelers. Zircon, for example, hyacinth of jeweler's grade as to size, transparency and color can only be expected next to magmatic rocks that contain zircon at sufficient size. Zirconium-bearing pegmatites are closely related to mantle derived magmatic intrusions such as peralkaline miaskitic and agpaitic rocks, e.g., Zomba, Malawi [10,61] (Figure 12b-d). Another source of multicolored gem-quality zircon is found in alkali basalts in Myanmar and Cambodia from which they get released during weathering [79,80]. Only recently in SE Germany such multicolored well-rounded zircon grains were identified as xenocrysts in alkaline volcanic rocks (basaltic lavas, nepheline basanites, and olivine nephelinites) genetically related to the Eger/Ohře Rift [81]. The gem-quality zircon from the alkaline basaltic source rocks is not only different with regard to its color, but also with regard to grain morphology. The zircon grains originating from pegmatitic source rocks in alluvial placer deposits appear with their crystal morphology well-preserved, whereas the zircon from the basaltic source rocks are well rounded or sub-rounded. No faces or edges are still preserved. It is not a suite of water-worn grains smoothed by the running water. Their shape has been preserved on release from the basalt and on transport to the proximal placer as can be deduced from a simple comparison of xenocrysts in the basaltic source rock and in the placer deposits, where zircon is associated with ilmenite, spinel, and corundum [81]. The high preservation potential of grain morphology sparked an intensive study whether the crystal morphology of zircon is a function of its physical-chemical conditions of [82-86]. The investigations of crystal morphology of zircon are very encouraging and the results can also be applied to heavy mineral accumulations in order to identify the source rock [87]. The three crystal morphologies 1-3 feature stubby crystals with a predominance of the pyramid over the prism, which becomes almost nil in type 3 (Figure 12d). Types I and II are indicative of a temperature around $600{ }^{\circ} \mathrm{C}$, while type 3 points to a temperature interval 500 to $550{ }^{\circ} \mathrm{C}$. The morphological types 1 to 3 of the opaque minerals correspond to zircon which has been derived from pegmatites. The multicolored zircon grains are rounded and do not allow us to label the faces with the Miller's indices in the common way for an attribution of the zircon grains to a peculiar type of zircon morphology. If an attempt is made to approximate the prismatic crystals of the yellow and red zircon grains a shape like that on display in Figure $12 \mathrm{~d}$ provides the best fit (Figure 12d). Using the data from Pupin [82] the temperature of formation of this elongated zircon crystal stands at a T value of more than $900{ }^{\circ} \mathrm{C}$, a fact in full agreement with the origin of these placer-type minerals sourced by basic magmatic rocks which are also of attraction to gemologists. What does the color of the zircon grains in the placer deposits tell us about the origin of the heavy minerals in question? Rozendaal and Philander [77] listed some chemical elements which act as chromophores in zircon. Colorless zircon has low contents of Fe, U, and Th. Pink to red zircon is enriched in REE (Rare Earth Elements), U, and Th. Yellow zircon is abundant in REE, U, Th, and abundant in $\mathrm{Fe}, \mathrm{Al}, \mathrm{P}$, and $\mathrm{Ca}$. Metamictic zircon grains contain $\mathrm{U}$, locally, in the range of as much as some wt \% and they are very much abundant in REE, Fe, and Y. These zircons suffering from radiation damage of their lattice have no high preservation potential and even if they might be used as 
a pathfinder to primary radioactive deposits, their application is limited in practice to the proximal clastic dispersion halo of $\mathrm{U}$ and $\mathrm{Th}$ mineralization.

\subsection{Garnet-Bearing Gemstone Placers}

Garnet-group minerals belong to the most common heavy minerals of intermediate stability. They have been derived from a wide range of source rocks (Figures 8 and 13) [88]. Pyrope is common to basic and ultrabasic magmatic rocks and their metamorphic equivalents, as exemplified by the well-rounded grains and subangular aggregates of pyrope, which has been released during weathering and denudation from alkaline basanites and olivine basalts, Mongolia [7] (Figure 13a,b). A pink pyrope-almandine garnet-group mineral is called rhodolite, which is among others mined from placer deposits in British Columbia, Canada (Figure 13c) [89]. The spessartine (a member of garnet-group minerals, with Mn as major element) frequently shows up in well-shaped crystal morphologies in placer deposits (Figure 13e). Primarily, it forms in pegmatites, granite-related mineralization, as well as low to medium grade mica schists, provided they are abundant in Mn $[9,10]$. A well known example of this manganese variety named, due to its color, as "Mandarin Garnet" and after the most prominent river in the region as "Kunene Garnet" was mined in the Marienfluss-Hartmannberge claims, an area where metamorphosed Mn-bearing rocks of probable sedimentary-exhalative origin occur [90]. It was found in alluvial-fluvial sediments of the Cuvelai-Etosha Basin, Namibia, close by [87]. Grossular originating from metacarbonate rocks is also a common garnet in placer deposits (Figure 13g). Grossular was originally named "cinnamon stone" ("Kanelstein" in German) and renamed grossularite. The current name which originates from the color of gooseberries (Ribes grossularium)) normally has a greenish tint, while a rare member of this grossular subgroup called hessonite stands out by it brown mineral color, which renders it of great interest for jewelers (Figure 13d). The most widespread red to brown garnet species originating from metapelitic rocks is almandine. It is the most resistant member of this garnet heavy mineral suite which was arranged in increasing order of abundance and resistance to weathering. Garnet is almost present in all placer deposits from the residual placers down to the coastal placer deposits (Figure $13 \mathrm{~h}-\mathrm{j}$ ). The grain morphology of garnet is an excellent mirror image of these different types of placers, yet the outward appearance cannot be used when considering the provenance of the various garnet members. Gemstones can only be expected near their source rocks-see above-in residual to alluvial placers, while grinding of garnet grains on fluvial transport and reworking them by the waves along lake or sea shores significantly reduce the grain size so that they can no longer be categorized as jewelers' grade but only recovered as an abrasive grade by-product (Figure 13j). Many of these modern marine garnet placers were formed as interstadial placer deposits in the shore-face to inner-shelf, e.g., Cape Ortegal, NW Spain [91]. The major garnet production derives from placer deposits along the Southern coast of Tamil Nadu, India [92]. Western Australia is also among the major supplier of industrial garnet with most garnet being produced from the mining operation at Port Gregory. Almandine is in this site associated with ilmenite and zircon [93]. All of them have to be denominated as industrial minerals in the strict sense. All members of the garnet group minerals may be observed in the various placer deposits, however, dominated by the red and brown varieties. In the aeolian placer deposits at Biluut uul and Elsteingol, Mongolia, almandine prevails. It has to be noted that in the majority of cases garnet is won as a by-product in placer mining, while the entrepreneurs keep an eye on precious corundum, spinel or diamonds, a group of gemstones that are used to fetch a higher price than garnet, excluding some very rare varieties of the grossular such as tsavorite or hessonite. 

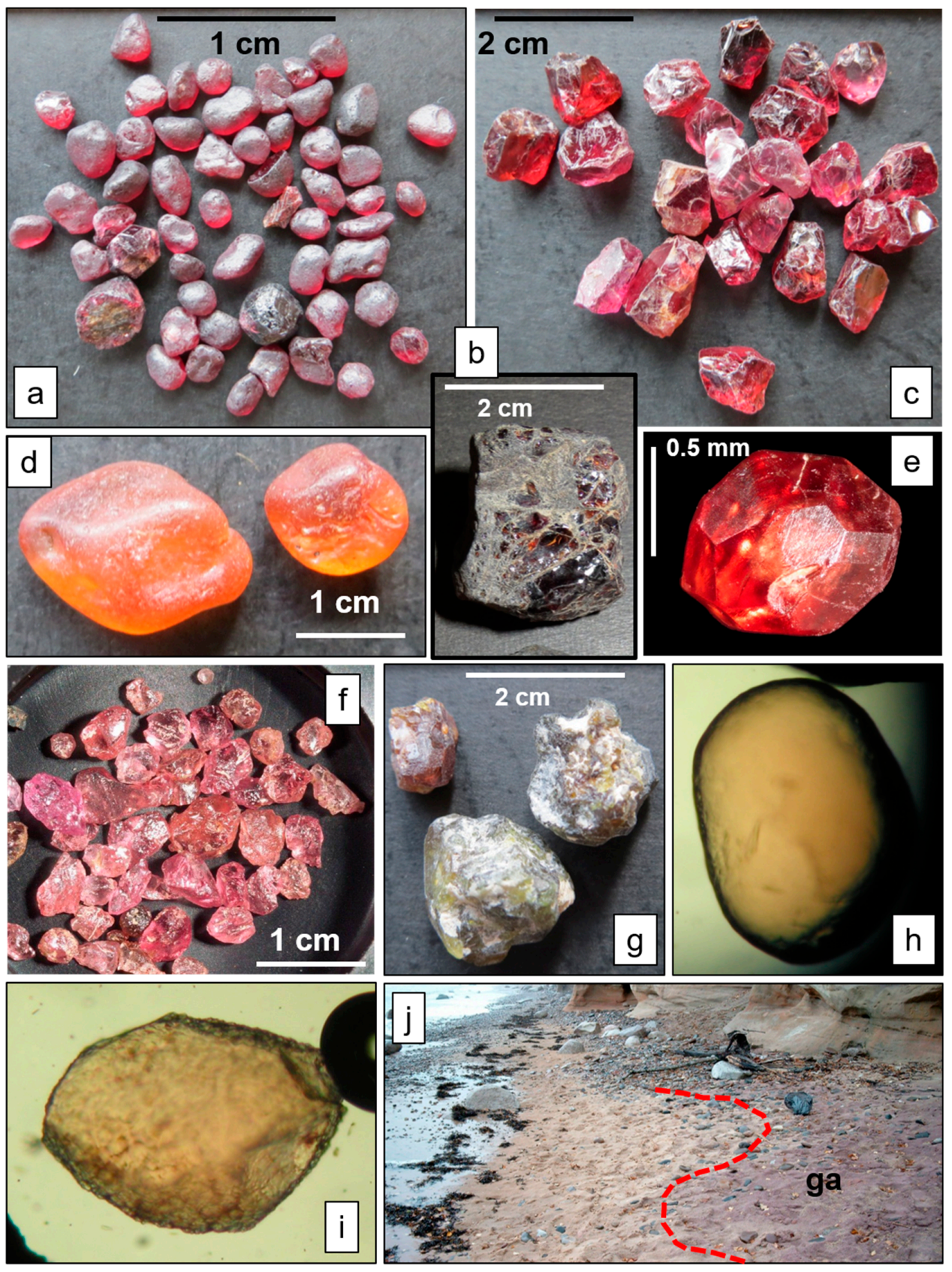

Figure 13. Garnet from placer deposits. (a) Well rounded pyrope-enriched garnet grains from fluvial placer, about $1 \mathrm{~km}$ downstream of the pyrope aggregate of Figure 13b. (b) Pyrope-enriched garnet cluster from a colluvial placer, Mongolia. (c) Rhodolite fragments from an alluvial placer, Madagascar. (d) Hessonite grains with beveled edges from an alluvial-fluvial placer, Tanzania. (e) Spessartine-enriched almandine garnet-group minerals, derived from pegmatitic and aplitic rocks from a fluvial placer (small creek), SE Germany. (f) Almandine garnet derived from paragneisses reworked into an alluvial-fluvial placer, SE Germany. (g) Grossular aggregates and grains from an alluvial placer, Malawi. (h) Micrograph of a well-rounded garnet from a beach placer (thin section, plane-polarized light, size approx. $300 \mu \mathrm{m}$ ), Bight of Riga, Latvia. (i) Micrograph of an angular garnet with etch pits from a residual to alluvial placer, (thin section, plane-polarized light, size approximately $300 \mu \mathrm{m}$ ), Malawi. (j) Small arenaceous strand plain with a cliff carved out of Devonian sandstones (Veczemji Cliff, Latvia). The garnet accumulation ("red sands") of the beach placer in the backshore is marked by a red dashed line from the seaward clean white beach sand spread across the foreshore. 


\subsection{Corundum and Spinel-Bearing Gemstone Placers}

In nature, the "worst enemy" for $\mathrm{Al}_{2} \mathrm{O}_{3}$ to form corundum or spinel in primary deposits is silicon, which in almost all environments is present in excess and consequently fosters the formation of alumo-silicates such as sillimanite or staurolite and hence contributes to the rarity of corundum deposits. However, a desilicified environment undergoing high $\mathrm{P}$ and $\mathrm{T}$ conditions would not yet yield precious but at the best opaque corundum. It needs chromophores like trivalent chromium to make a ruby or sapphire, the involvement of multiple ions such as in sapphire as well as color centers. This accounts for why precious corundum ruby, sapphire, and padparaja are so rare despite of their extraordinary hardness, which only trails behind diamond by one point in the Mohs hardness scale. The situation is not any better for the common spinel in nature. Considering the formula $\mathrm{XY}_{2} \mathrm{O}_{4}(\mathrm{X}=\mathrm{Mg}, \mathrm{Zn}, \mathrm{Fe}, \mathrm{Mn}, \mathrm{Y}=\mathrm{Al}, \mathrm{Cr}$, Ti, and $\mathrm{Fe}$ ) may give rise to a sloppy denomination of spinel s.s.s. as an "advanced corundum" and allows for their subdivision into $\mathrm{Al}, \mathrm{Fe}$, and $\mathrm{Cr}$ spinels. In Figure 14 the various placer types of precious corundum are shown using the morphology of the mineral grains and aggregates to distinguish the various types from each other. In primary deposits, which may be magmatic or metamorphic ruby, tends to crystallize in well-shaped euhedral crystals, as exemplified by the metacarbonates in Vietnam hosting remarkable ruby deposits [94] (Figure 14a). Chemical weathering affecting calcareous sedimentary units triggers karstification resultant in cavities filled with argillaceous material and crystals still well preserving their original shape (Figure 14b). Due to mechanical reworking by mass wasting processes such as landslides or mud flows and the running water the minerals get broken, but their fragments still allow for singling out red spinel grains from the overall red corundum (Figure 14c). In fluvial placers of the same mineral province in Northern Vietnam, the different grains of corundum have to pay tribute to the attrition. The morphology of ruby is much more obliterated than the crystal morphology of spinel whose octahedral faces can still be identified in panned heavy mineral assemblages (Figure 14d). The "brethren" of ruby, the white and blue sapphire follows the same path during weathering and the ensuing placer evolution. A mega-sapphire measuring 12 tons by weight has been smoothed by aquatic processes and constitutes a natural monument today in front of an office building (Figure 14e). A block like that can neither be moved by water worn in a river nor can it be chemically altered in-situ by a simple solution process. It needs a joint action of chemical weathering (residual placer) and a slurry characteristic of colluvial and alluvial processes which smoothed the faces and edges of the gemstone by some sort of natural abrasive paste (Figure 14e). Fragments like those shown in Figure $14 \mathrm{f}$ are worth considering as abrasives in the industry. Precious corundum may be expected downstream to the level of fluvial placer deposits in braided streams, where these colored gemstones often are accompanied by other gemstones such as garnet or iolite, a variety of cordierite. The commercially viable placers are found between residual and alluvial placers. Karstification has an upgrading effect on the secondary deposits as shown by the placers in Myanmar and Vietnam. In many mining districts, modern placers develop from paleoplacers, similar to what is also known from secondary diamond deposits [1] (Section 3.9). The mineral assemblage becomes downstream more variegated with heavy minerals of different stability groups, as shown by some examples [95]: Sapphire, spinel, garnet, chrysoberyl, topaz, tourmaline, andalusite, kyanite, and zircon. Sri Lanka recovers a great deal of its revenues from gemstones exploiting precious corundum with almost $90 \%$ of gems found in paleoplacers underneath the active river beds in alluvial gravels of Pleistocene to Recent age ("illam") [96-98]. Coastal placers do not play any significant role for corundum, e.g., Hainan. Only the Fe and Cr spinels are, in places, enriched in coastal placer deposits given basic and ultrabasic rocks are exposed in the hinterland [99]. 

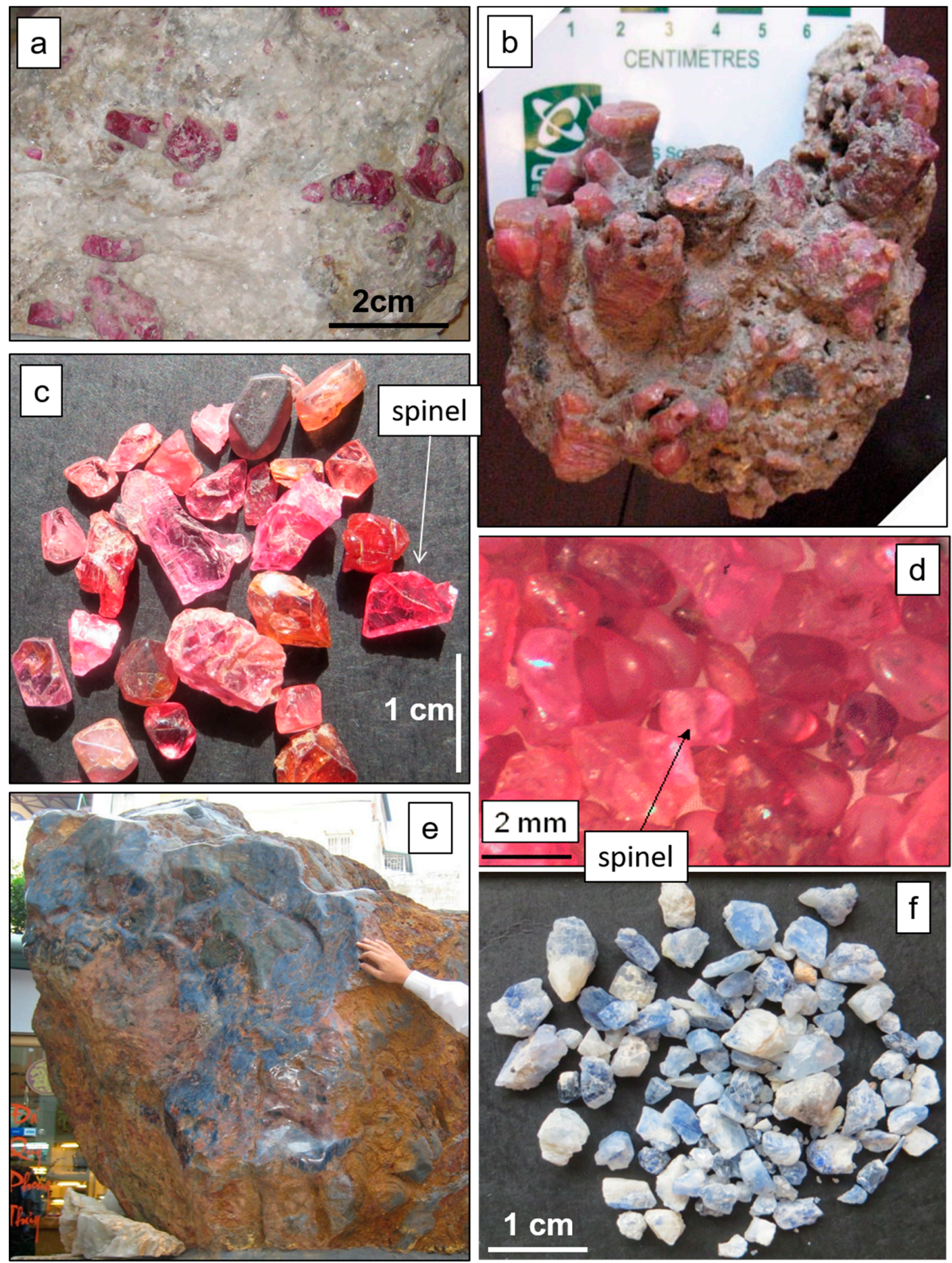

Figure 14. Precious corundum and spinel in placer deposits. (a) Euhedral to subhedral crystals of ruby in a pargasite-bearing marble (primary deposit), Vietnam. (b) Aggregate of ruby in a karst cavity of the marble, Vietnam, (residual placer). (c) Panned heavy minerals from a colluvial to alluvial placer of ruby and spinel (see octahedral crystal fragments), Vietnam. (d) Well-rounded grains of ruby with some subrounded octahedral of red spinel in a fluvial placer, Vietnam. (e) Sapphire measuring 12 tons by weight from a residual placer deposit, Vietnam. (f) Sapphire from a colluvial to alluvial placer, Madagascar.

\subsection{Diamond-Bearing Gemstone Placers}

Due to the extraordinary position taken by the diamonds in terms of their value and their physical properties, particularly hardness, these gemstones form an ideal heavy mineral that is 
recovered from the full spectrum of depositional environments to be identified among modern and paleoplacers deposits and has attracted the attention of many researchers from different geoscientific camps [100-107].

Sedimentary diamond deposits are closely linked with a peculiar geotectonic-geological setting, which is marked by three elements. The various placer deposits are in and around an ancient craton, be it exposed or hidden, which is pierced by subcrustal magmatic rocks belonging to the lamproite and/or kimberlite suite that act as host- and source-rock lithologies [108-113].

Rock-forming minerals common to these two source and host-rock lithologies of diamonds are used as pathfinder minerals in stream sediments and different placer types to find either profitable secondary or even primary diamond deposits. Forsterite is recorded in association with pyrope and chromium diopside from heavy mineral accumulations, as a pathfinder to diamondiferous source rocks $[114,115]$. Titanite is a very widespread Ti-bearing mineral among the heavy minerals, but in the stream sediments it issues, some sort of a "natural disclaimer" for diamonds in the basic source rocks. Ultrabasic host rocks of diamonds used to concentrate Ti in heavy minerals in an apron around like perovskite, titaniferous amphibole, and phlogopite, as well as ilmenite, all of which can show up in the placer deposits [7].

Paleoplacers are common repositories of diamonds in Africa and South America. Alluvial-fluvial gravel beds in the upper Karoo are operated at Somabula, Zimbabwe, not only for diamonds, but also for topaz, chrysoberyl, sapphire, ruby, and emerald [116]. In neighboring Angola, the upper Cretaceous "Calonda Deposits" are host to alluvial-fluvial diamond concentrations [117]. At a stratigraphically similar level, diamonds were found in the neighboring DR Congo within conglomerates of the upper Cretaceous Kwango Series. Between 100 and 80 Ma a strong uplift of the African Craton triggered the deposition of piedmont conglomerates and reworking of diamonds into different types of modern placer deposits (Figure 15a). Fossil placers in Carboniferous sandstones as well as alluvial deposits were mined in Brazil, Venezuela and Guyana where the primary source of diamonds is still enigmatic [118,119]. They were reworked into braided-stream sediments and deposits, which were derived from ephemeral flash floods [1].

The area most attractive for the recovery of diamonds from sedimentary deposits is without any doubt situated at the SW edge of the African continent where so-called mega-placers evolved around the Kaapvaal Craton [106]. Diamond mega-placers, have been defined as $\geq 50$ million carats at $\geq 95 \%$ gem quality by the aforementioned authors. Production figures were published by Porter GeoConsultancy Pty Ltd. (Linden Park, Australia) [120]. At the end of 2000, Namdeb reported remaining resources and reserves (land + marine) as follows: (1) Probable reserves of 59.4 Mt @ 1.5 carats per hundred metric tons (cpht), (2) indicated total resources of $73.6 \mathrm{Mt} @ 2.3 \mathrm{cpht}$, and (3) inferred total resources of 301.7 Mt @ 1.5 cpht. Porter GeoConsultancy Pty Ltd. (2004) [120] provided a brief overview, based upon which, the principal factors of the main concentration systems may be listed as follows:

(1) Fluvial diamond accumulation took place by the Orange-Vaal River drainage system for some $100 \mathrm{Ma}$. From the early Paleogene onward, continental uplift caused the drainage system to incise and create several diamond-bearing terraces between 19 and $17 \mathrm{Ma}$, and subsequently during 5 and $3 \mathrm{Ma}$.

(2) A wave-dominated delta at the mouth of the Orange River and the variations in sea level during the last 40 million years has produced a number of palaeo-shorelines with onshore "raised beaches" and offshore "submerged beaches" — see also Figure $6 \mathrm{f}$ - passing towards more recent periods into the formation of barrier beach and linear beach—see also Figure $6 a, b$.

(3) Strong winds working their way for 40 million years in the same direction in the arid climate of the Namib Desert caused a Northward-directed longshore current. In context with the marine currents, deflation basins, a combination of ephemeral run-off, salt weathering and aeolian action, in general, the concentration of diamonds was upgraded and aeolian placers were formed within the dune sands of the Namib Desert. 
(4) Offshore marine deposits are encountered as drowned placer deposits located in waters ranging from the surf zone near the coast, to a depth as great as $150 \mathrm{~m}$ on the shelf. Evidence to date suggests that the marine environments host the same complex range of beach-barrier, beach, deflation, and aeolian systems seen onshore [120].
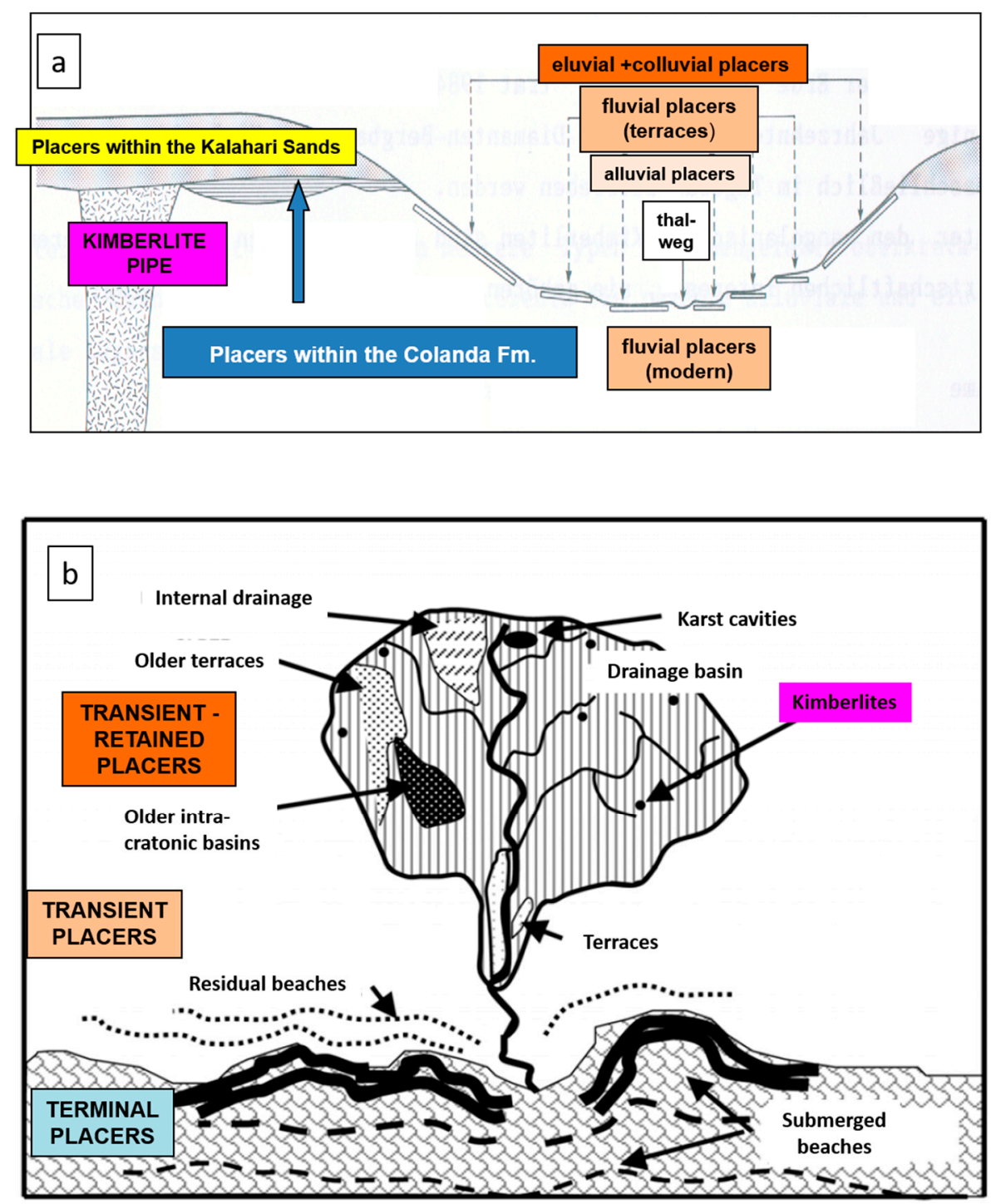

Figure 15. Diamond placer deposits in cross section [121]. (a) From the diamond-bearing pipe to the placer deposits. An idealized cross section illustrating the primary (kimberlite pipe), intermediate paleoplacers (Calonda and Kalahari placer sands) and final modern placer deposits of diamonds at midslope, footslope positions, and along the thalweg in the drainage systems in Angola (modified from [122]. (b) Cartoon to illustrate the tripartite subdivision of diamond placers into retained, transient, and terminal placer deposits leading to the modern-day mega-placers in Southern Africa (modified from [106]).

A different picture can be drawn based upon the studies of Bluck et al. [106] who placed more emphasis on a higher level in the hierarchy of placer deposition and provided a tripartite categorization of these diamond placers into (1) retained placers, (2) transient placers, and (3) terminal placers which reflect a combination of modern and paleoplacers systems and take into consideration the peculiar physical-chemical characteristics of diamonds (Figure 15b). The different levels can be combined and are also used to illustrate how the placer aprons evolve around a basement high of metacarbonate or metasilicate rocks (Figure 1). The latter properties established by Bluck et al. [106] take particular 
effect during the variation of the geodynamic setting which the diamond grains went through on their transit from the primary magmatic kimberlitic rocks more than $1 \mathrm{Ga}$ ago to the final modern-day placer deposits. The tripartite classification scheme of Bluck et al. [106] does not replace the existing classification scheme applied in the current study, but combines some sedimentological processes with the geodynamic setting with a clear focus on diamonds-see also Figure 1.

Retained placers: The two major sedimentary traps to retain diamonds released from the kimberlites, in places, $>2.5 \mathrm{Ga}$ ago, are intracratonic basins and karst cavities resembling those traps described for precious corundum deposits in Myanmar and Vietnam (Figure 15b). It is the potholes and paleoriver systems which contain the diamonds scattered between gravels, mainly entrained in lag deposits similar to what has been shown in Figure $4 \mathrm{~g}$. Some of the gravel deposits stand out from the surrounding landscape like esker in a glacial terrain reflecting an inversion of the relief. In a glacial landscape, ice has melted away causing ridges of coarse sediments to emerge and stand out like a railway embankment. In the diamondiferous landscape it is the less soluble material, the calcareous rock which when being dissolved in the course of karstification provoke siliceous sedimentary material to stand out in a similar way [123]. Large intracratonic basins are the second important depocenters covering a wide variety of terrigenous sediments mainly of coarse grain size and chemical sediments such as calcretes marking hiatuses. Since the break-up of Gondwana thick siliciclastic series with a Middle Mesozoic through a Cenozoic stratigraphic record evolved there. Extensional periods affecting the Archean-Proterozic cratons, on one hand, were conducive to large basins acting as trap-sites for placers, and on the other hand, concealed diamond-bearing kimberlites. An example for this category of diamond placers is given in Figure 15a grading from the retained into the transient placers.

Transient placers: According to Bluck et al. [106] transient placers are diamond-bearing sediment piles stored along the dispersal route or within the active drainage basin. This category of placers occurs in terraces and they are strongly controlled by the aforementioned ratio of uplift and weathering which affects the dispersal and concentration of diamonds in an indirect way due to its outstanding physical-chemical features compared to the surrounding country rocks. The transient placers, exemplified by the Orange River drainage system in SW Africa can be considered as an intermediate repository or protoplacer for the final step or mega-placer to come. However, it can also upgrade to a placer system in its own right, depending on the efficiency of its fluvial drainage system in collecting the diamonds. Jacob et al. [124] investigated the Lower Orange River drainage system and its terraces demonstrated the change of size and grade along with the stratigraphic evolution. The highest grade was reached during the Oligocene (?) with high background grades extending into the terminal placer.

Terminal placers: The terminal placer marks the end of the "flow path of the natural processing plant of diamonds". The quality of the concentration process in the marine environments depends upon different parameters enhancing, on one side, the accumulation of diamonds while reducing the amount of the dilutors both of which are provided by the nearby craton in the hinterland [106]. The essential parameters for the built-up of the diamond mega-placers in Southern African are listed as some bullet points according to the aforementioned authors:

The potential dilutor of the diamond placers, the Karoo overburden was removed during the Cretaceous and dumped in subsiding basins

Incision of a pre-existing (mainly Cretaceous) drainage systems to access newly exposed primary and pre-concentrated diamond deposits during the Tertiary

A high-energy wave-dominated coastal regime with a unidirectional wind over a shelf and a point-source delivery system active at the same time (Figures 5 and 6 )

The final dispersal should be young and unlithified to facilitate mining.

Large basins hosting known or potential trap-sites of diamonds along and around ancient cratons are not only located in South Africa, but are also found in Angola, Niger, DR Congo, Chad, Senegal, Mauretania, Western Australia, Siberia, North, and South America, mainly in Brazil, where glaciation is held to be a principal exogenous process for the deposition of diamonds [108]. The authors singled out three periods relevant for the accumulation of diamonds, the first one during the Early Proterozoic, 
designated the Jequital glaciation, the second one was dated as Cambrian, which is represented by the Santa Fé Tillites, and the last one operative during the Carboniferous being called the Itarar.

\subsection{Quartz-, Diopside-, Titanite-, Olivine-, Epidote- and Spodumene-Bearing Gemstone Placers}

There are several minerals that fall in a grey area, whether these minerals are true gemstones by definition or not and accordingly their accumulation in sedimentary rocks forms part of what might be called a gemstone placer. The most common contenders of them are siliceous minerals and treated in this overview for the sake of completeness as only silicates are capable of surviving the chemical and physical processes involved the formation of placers. Even if some sulfides and oxides such as pyrite, sphalerite or hematite are exploited for their aesthetic value in some deposits, none of them ends up in placers in a quality coming close to what might be called "gemmy" [1].

Quartz is not a heavy mineral in the strict sense, quite the contrary, it is the "standard mineral" among the light minerals, but nevertheless, some of its varieties warrant mentioning because they are found in placer deposits and can be won from the stream sediments for a profit. One of these varieties is famous for its well-shaped clear crystals, called "rock crystals", another one is known for its blue to purple color called amethyst, and the third in the row is the multicolored agate, a variety of chalcedony (fine-grained quartz). (Figure 16a). Especially rock crystals may form placer deposits of economic interest for the purity of their silica grains [125]. Double-terminating ones, however, may suffer from transport when their edges get beveled and the pointed pyramids broken. Therefore, they are better preserved in the loamy substrate of residual placers where those minerals are recovered to satisfy the demands of gem collectors. In the Donghai County of Eastern China, rock crystal-bearing quartz veins occur in the Su-Lu ultra-high pressure metamorphic belt. Uplift and denudation of this metamorphic host complex created a large apron of alluvial-fluvial placer deposits during the Quaternary hosting these quartz crystals [126,127]. Near-source alluvial placers of rock crystals are also known from Madagascar and from Sri Lanka. The most well known alluvial-fluvial deposits of amethyst in Brazil occur on the banks and in the fluvial terraces of the Araguaia River [112]. Agate has been found among the gravel of the Mormora River in the Sidoma Province, Ethiopia, and mined at an economic grade.

Two other silicate minerals also deserve treatment among the group of gemstones concentrated in alluvial to fluvial placer deposits. It is diopside and titanite with their vivid green varieties accommodating chromium in their lattice which are the most popular ones with gemstone collectors and exploration geologists who use them as pathfinder minerals during diamond exploration (Figure 16b,c). Apart from its marker mineral character for kimberlite pipes, the chrome diopside is also found at metal deposits devoid of diamonds, e.g., Outukumpu, Finland. In general, titanite is not very common in placer deposits, mainly due to its limited occurrence in primary deposits and moderate mineral strength (Figure 8). To demonstrate the variation of the amount of titanite, together with its associated heavy minerals along transport, in Table 3 the different heavy mineral suites and lithoclasts communities are listed as a function of the different placer types from the source rock through the tributary river to the trunk river in Central Mongolia (see also the section on diamonds-Section 3.8). The distance of transport from the basic source rocks to the trunk river measures approximately 1500 $\mathrm{m}$ and the difference in height between the two sites is about $250 \mathrm{~m}$. The reason why titanite together with a series of rather unstable heavy minerals was able to survive in these placer types, different to their sedimentological processes of formation is explained by the high ratio of uplift vs. chemical weathering. The latter process is controlled by a rather cold climate in Central Mongolia that did not favor a pervasive chemical, but rather physical weathering. All heavy minerals observed in the placers are rather well preserved, excluding the least resistant mineral olivine the grains of which in the placer show strongly serrated rims as being compared to its source-rock-hosted subrounded phenocrysts (Figure 16d,e). The distance of transport also plays a significant role in the marine placer deposits resulting in the "green beaches" of Hawai, USA. Chemical weathering cannot keep pace with the newly vented amounts of pyroclastic and volcanic parent material and the coastal erosion in the 
swash zone both of which are working hand in hand in exposing permanently new material for the reworking into beach placer deposits. The two examples of olivine placers referred to in the current study furnish clear evidence that the formation of the landscape by exogenic and endogenic processes cannot be cast aside and give the sole answer why heavy minerals from the opposite ends of the scale of stability appear in the same placer type (Figure 8).
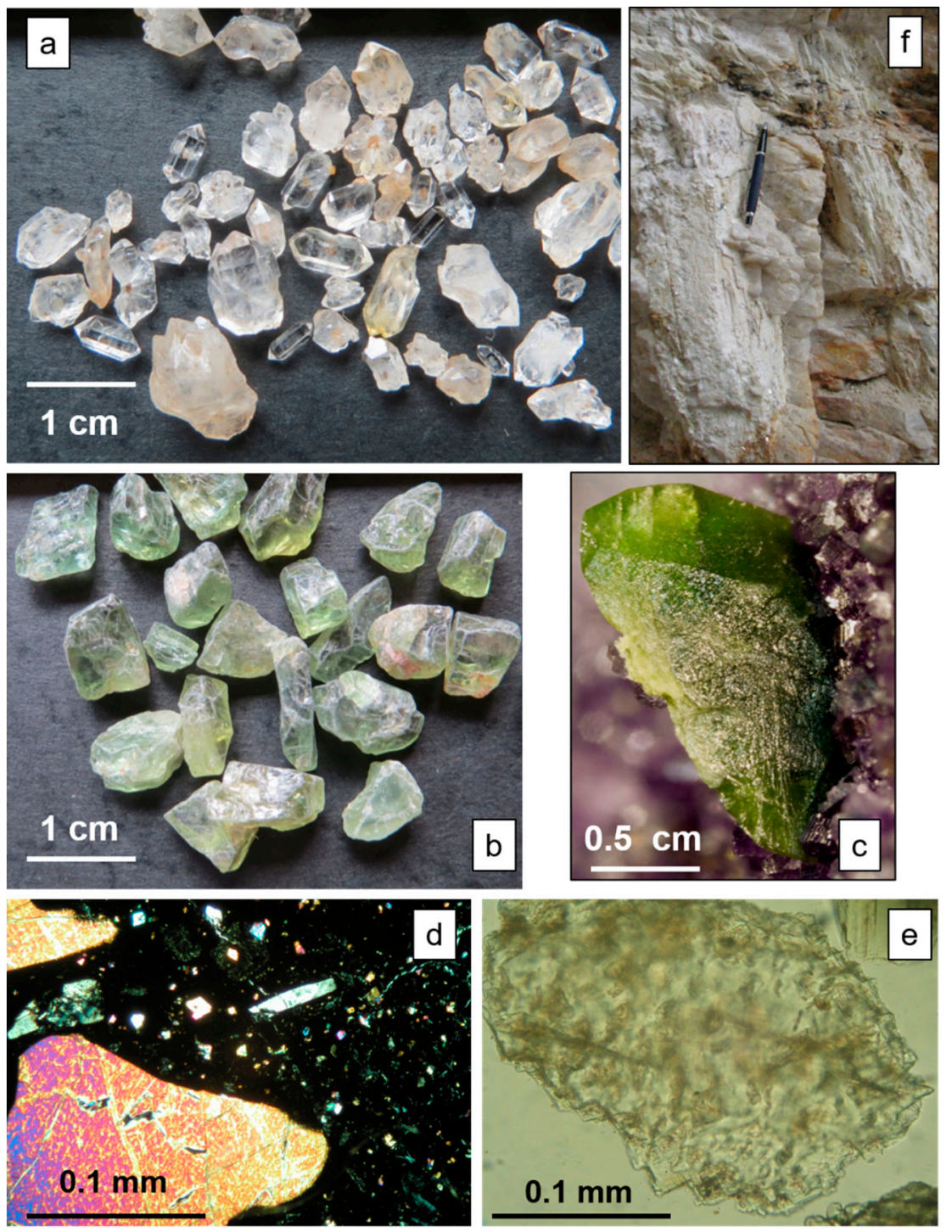

Figure 16. Silicates of rare occurrence in placer deposits. (a) "Rock crystals" of double-terminated quartz washed out from placer deposits, Madagascar. (b) Panned diopside crystals from placer deposits, Madagascar. (c) Chromium-bearing titanite from the Ural Mts., Russia (rotated for display by $90^{\circ}$ ). (d) Micrograph of subrounded phenocrysts of olivine besides angular microphenocrysts of plagioclase floating in a basanitic host rock, Mongolia (crossed polars). (e) Olivine strongly corroded during transport and weathering in a fluvial placer deposit of a tributary stream proximal to the basanitic host rock—see Figure 16c, Mongolia (panned heavy mineral concentrate, plane polarized light). (f) Green spodumene gradually alters to cookeite at the edge of a pegmatite in Minas Gerais, Brazil. See biro for scale. 
Table 3. Lithoclast- and heavy mineral variation along the thalweg from the primary source through the different colluvial, alluvial and fluvial placer deposits in a diamondiferous olivine-garnet placer deposit, Mongolia (modified from Dill et al.) [7]

\begin{tabular}{|c|c|c|}
\hline Environment & Lithoclasts & Heavy Minerals \\
\hline Primary deposit & $\begin{array}{l}70 \% \text { volcanites (olivine basalt, bassanite, trachybasalts), } \\
30 \% \text { tuffaceous breccia composed mainly of fragments } \\
\text { of shales, sandstones, crystalline rocks and } \\
\text { volcaniclastic material }\end{array}$ & $\begin{array}{l}\text { olivine, titanite, garnet (pyrope-enriched), garnet } \\
\text { (almandine-enriched), zircon, clinozoisite, epidote (pistazite), amphibole }\end{array}$ \\
\hline $\begin{array}{l}\text { Secondary colluvial to alluvial } \\
\text { placer deposit }\end{array}$ & $\begin{array}{l}50 \% \text { volcanites, } 20 \% \text { tuffaceous breccia, } 20 \% \text { crystalline } \\
\text { rocks, } 10 \% \text { olivine-garnet aggregates }\end{array}$ & $\begin{array}{l}\text { titanite, garnet (pyrope-enriched), garnet (almandine-enriched), } \\
\text { olivine, zircon green amphibole, brown amphibole, } \\
\text { tremolite-actinolite, apatite, epidote (pistazite), clinozoisite, orthopyroxene } \\
\text { (bronzite, hypersthene), clinopyroxene, biotite, spinel }\end{array}$ \\
\hline $\begin{array}{l}\text { Fluvial placer deposits (proximal } \\
\text { tributary stream) }\end{array}$ & $\begin{array}{l}20 \% \text { volcanites, } 10 \% \text { tuffaceous breccia, } 30 \% \text { crystalline } \\
\text { rocks, } 20 \% \text { granitic fragments, } 20 \% \text { shales / slates }\end{array}$ & $\begin{array}{l}\text { titanite, green amphibole, brown amphibole, olivine, epidote } \\
\text { (pistazite), garnet (almandine-enriched), zircon, apatite, orthopyroxene } \\
\text { (bronzite, hypersthene), spinel, andalusite }\end{array}$ \\
\hline $\begin{array}{l}\text { Fluvial placer deposits (intermediate } \\
\text { tributary stream) }\end{array}$ & $\begin{array}{l}20 \% \text { volcanites, } 10 \% \text { tuffaceous breccia, } 30 \% \text { crystalline } \\
\text { rocks, } 20 \% \text { granitic fragments, } 20 \% \text { shales / slates }\end{array}$ & $\begin{array}{l}\text { titanite, green amphibole, brown amphibole, zircon, epidote } \\
\text { (pistazite) apatite, garnet (almandine-enriched), monazite, tourmaline, } \\
\text { fayalite-enriched olivine, hypersthene, }\end{array}$ \\
\hline $\begin{array}{l}\text { Fluvial placer deposits (distal } \\
\text { tributary stream) }\end{array}$ & $\begin{array}{l}10 \% \text { volcanites, } 5 \% \text { tuffaceous breccia, } 50 \% \text { crystalline } \\
\text { rocks, } 10 \% \text { granitic fragments, } 25 \% \text { shales / slates }\end{array}$ & $\begin{array}{l}\text { titanite, green amphibole, brown amphibole epidote (pistazite), } \\
\text { zircon, apatite, garnet (almandine-enriched), (pyrope-enriched), orthite }\end{array}$ \\
\hline Fluvial placer deposits (trunk river) & $\begin{array}{l}10 \% \text { volcanites, } 60 \% \text { crystalline rocks, } 10 \% \text { granitic } \\
\text { fragments, } 20 \% \text { shales / slates }\end{array}$ & $\begin{array}{l}\text { titanite, green amphibole brown amphibole, epidote (pistazite), } \\
\text { garnet (almandine-enriched), (pyrope-enriched), fayalite-enriched } \\
\text { olivine, zircon, apatite, forsterite-enriched olivine, hypersthene }\end{array}$ \\
\hline
\end{tabular}

minerals: Abundant (bold-faced), common (normal font), rare (italics). 
Epidote-clinozoisite s.s.s. (s.s.s. = solid solution series) are common heavy minerals of intermediate stability and found in many siliciclastic sediments, but only the blue tanzanite attracted the interest of gem dealers. As to its presence in placer deposits, it closely resembles garnet-group minerals, as to its abundance of mineral grains attaining gem quality, however, it trails far behind garnet. Profitable finds are only to be expected in proximity to the primary gemstone deposits (Figure 8).

Another gemstone is referred to only for completeness in this review of gemstone placer deposits. Spodumene a Li silicate typical of pegmatitic source rock has two varieties, kunzite, and hiddenite that qualify for being ranked among gemstones. Spodumene is only present in the clastic apron close to the source pegmatite [34]. Similar to its companion petalite it decomposes easily into phyllosilicates such as cookeite, smectite and kaolinite depending upon the physical-chemical conditions (Figure 16f). Not surprisingly, precious spodumene is a very rare species in placer deposits and rose-colored kunzite was only reported from Minas Gerais to be mined from some alluvial deposits. The majority of this gemological variety of spodumene with the largest crystal ever found near Conselheiro Pena weighing $7.410 \mathrm{~kg}(=37,050$ carats $)$ has been recovered from pegmatites [112].

\subsection{Amber Placer Deposits}

Baltic amber originates from resin of a pinaceous conifer similar to Pseudolarix [128]. The original deposits formed from the Eocene to the Early Oligocene in a nearshore marine environment along the eastern Baltic Sea coast (Jantarnyj and Svetlogorsk in East Prussia on the Semba Peninsula, Russia), while another site is located near Darłovo, Poland $[1,129,130]$.

The amber units were reworked and re-deposited during the Quaternary and placer-like accumulations are now also found along the Polish coast [131]. Holocene amber deposits are widespread along the coast of the Baltic Sea up to the Kuršiu Marios lagoon. Nirgi et al. (2017) [132] reported amber-bearing layers from the Holocene coastal plain on the SW Saaremaa Island where amber is not known in sedimentary successions, but is common in Stone Age and Bronze Age archaeological sites. Amber cannot be grouped among the heavy minerals and the rules of settling and entrainment equivalence can hardly be applied to the majority of these organic compounds (Figure 7). Due to its specific gravity of between 1.05 and 1.08 amber can float on saltwater and frequently occurs in marine environments after having been transported over a long distance from its original site of formation [133]. Its transport does not need strong longshore currents, although strong surge eases long distance-transport and its release from pre-existing amber beds. Amber is also found in fluvial deposits, such as oxbow lakes and slack-water facies [133]. Both subenvironments of meandering stream deposits are not the preferred loci to concentrate heavy minerals and create fluvial placer deposits owing to its low speed of the water currents. After being released from its primary beds such as coal, it can survive reworking provided it is protected from being exposed to oxygen for a long period of time. In places, amber is rafted bound to waterlogged wood and concentrated together with this drift wood. Due to the moderate hardness placer-like accumulations of amber are found mainly in young sedimentary units from the Paleogene through to the Holocene.

\section{Synopsis and Conclusions}

Of the approximately 150 gemstones, roughly 40 can be recovered from placer deposits for a profit after having passed through the natural processing plant of weathering, transport, attrition, and deposition (agate, almandine, amber, amethyst, apatite, aquamarine, beryl, (chrome) diopside, (chrome) tourmaline, chrysoberyl, citrine, demantoid, diamond, emerald, enstatite, hessonite, hiddenite, kornerupine, kunzite, kyanite, morganite, peridote, pyrope, quartz, rhodolite, rose quartz, smoky quartz, spessartine, (chrome) titanite, spinel, ruby, sapphire, tanzanite, zoisite, topaz, tsavorite, and zircon). Going downhill from the source area to the basin means in effect separating the wheat from the chaff, the showcase from the jeweler's quality, because only the flawless and strongest contenders among the gemstones survive it all. Some of these gemstones can also be used as pathfinder minerals 
for primary or secondary gemstone deposits of their own together with a series of other non-gemmy materials which are genetically linked to these gemstones.

All placer types known to be relevant for the accumulation of non-gemmy material such as gold, cassiterite, ilmenite, "coltan" - group s.s.s. etc. are also found as trap-sites of gemstones (residual, eluvial, colluvial, alluvial, deltaic, aeolian, and marine shelf deposits) (Figure 1). Running water and wind can separate minerals according to their physical-chemical features; ice can only transport minerals and rocks. Only in the glacial-fluvial sands and gravels of the outwash plain in front of the terminal moraine and between this moraine and the retreating glacier the sorting and separating influence of running water can take effect. This does not mean that glacial or periglacial landforms have to be confined to play a subordinate role in this matter [134]. The techniques used in till exploration to delineate an ore body of whatever commodity it may be, can also be used for gemstones shown in Table 1 and in the previous paragraph, but in practice it is only worth the trouble for diamonds and in some places for modifications of precious corundum. In addition to the marker minerals listed for diamond exploration in Section 3.8, it is particularly the Cr-enriched varieties of pyrope and almandine, pyroxene, spinel, $\mathrm{Mg}$ ilmenite, and $\mathrm{Mg}$ olivine that count [135]

The general parameters that matter during accumulation of gemstones in placers are their intrinsic value controlled by the size and hardness and the extrinsic factors controlling the evolution of the landscape through time such as weathering, erosion and vertical movements, and fertility of the hinterland as to the minerals targeted upon. The impact of both parameters can be demonstrated by the most unstable gemstone peridote (olivine) and the ultrastable gemstone diamond (Figures 1 and 8). Olivine does not survive long-term pervasive chemical weathering widespread in tropical morpho-climatic zones where this $\mathrm{Mg}-\mathrm{Fe}$ silicate ends up in a great variety of $\mathrm{Ni}-, \mathrm{Co}$, and $\mathrm{Cr}$-bearing serpentine, chlorite, smectite, talc, and sepiolite-group phyllosilicates called "garnierites" [33,34]. Chemical weathering has two maxima, a first-order one in the humid tropical zone and a second-order one in the humid mid-latitude zones. It has two minima in the periglacial/glacial zone and the high-altitude/mountain zone, where mechanical weathering prevails over chemical weathering, erosion, and the gradients are high. In those environments typical of a high rate of erosion vs. chemical weathering even the unstable peridote can appear in marine and fluvial heavy mineral assemblages in a proximal placer. Due to its stability, diamonds are left unaffected by those issues mentioned above and can be recycled in a multi-stage process. A critical aspect during deposition of ultrastable gemstones such as diamonds is the covering and diluting effect exerted by the sediments laid down concomitantly with the gemstones. High energetic aquatic and aeolian winnowing processes can remove the dilutors from the various trap-sites, a fact which is also underscored in different placer deposits by lag deposits residing immediately on top of the bedrock. Some tectono-geographic elements such as unconformities, hiatuses, and sequence boundaries (often with incised valley fills and karstic landforms) and known as common planar architectural elements in sequence stratigraphy applied to marine and correlative continental environments can play a significant role in forward modeling of placer deposition.

Funding: This research received no external funding.

Acknowledgments: I acknowledge with thanks the fruitful comments made by the three reviewers. My sincere thanks are extended to the guest editors of the special volume "Mineralogy and Geochemistry of Gems" Panagiotis Voudouris, Stefanos Karampelas, Vasilios Melfos, and Ian Graham for their invitation to make a scientific contribution to the special volume and their editorial assistance. I extend my gratitude also to the team of "MINERALS" for the technical support and for the final layout. I would like to thank also my former colleagues W. Hofmeister and T. Häger (Johannes-Gutenberg University Mainz, Section: Geo-Materials and Gemstone Research).

Conflicts of Interest: The author declares no conflict of interest.

\section{Appendix A. See Text for Reference}

Studies of economic geology sensu lato are centered on the emplacement of the ore body and the development of its minerals and rocks. As a consequence the "Chessboard Classification Scheme of Mineral Deposits" uses mineralogy and geology as x- and y-coordinates of a classification chart 
of mineral resources resembling a "chessboard" (or "spreadsheet"). Magmatic and sedimentary lithologies together with tectonic structures (1-D/pipes, 2-D/veins) are plotted along the $\mathrm{x}$-axis in the header of the diagram representing the columns in this chart diagram. 63 commodity groups, encompassing minerals and elements are plotted along the y-axis, forming the lines of the spreadsheet. These commodities are subjected to a tripartite subdivision into ore minerals, industrial minerals and gemstones/ornamental stones. Further information on the various types of mineral deposits, as to the major ore and gangue minerals, current models and mode of formation or when and in which geodynamic setting these deposits mainly formed throughout the geological past may be obtained from the text of "Chessboard Classification Scheme of Mineral Deposits" by simply using the code of each deposit in the chart. This code can be created by combining the commodity (lines) shown by numbers plus lower caps with the host rocks or structure (columns) given by capital letters. Each commodity has a small preface on the mineralogy and chemistry and ends up with an outlook into its final use and the supply situation of the raw material on a global basis, which may be updated by the user through a direct link to databases available on the internet, e.g., the database of the US Geological Survey. The internal subdivision of each commodity section corresponds to the common host rock lithologies (magmatic, sedimentary, metamorphic) and structures. Cross sections and images illustrate the common ore types of each commodity.

Table of contents: Chromium, nickel, cobalt, platinum group elements (PGE/platinum palladiumosmium-iridium-rhodium-ruthenium), titanium, vanadium, iron, manganese, copper, selenium-tellurium, molybdenum-rhenium, tin-tungsten, niobium-tantalum-scandium beryllium, lithium-cesium-rubidium, lead-zinc-germanium-indium-cadmium, silver, bismuth, gold, antimony, arsenic, thallium, mercury, rare earth elements (REE/lanthanum, cerium, praseodymium, neodymium, promethium, samarium, europium, gadolinium, terbium, dysprosium, holmium, erbium, thulium, ytterbium, lutetium)yttrium, uranium-radium, thorium, aluminum-gallium, magnesium, calcium, boron, sulfur-calcium sulfate, fluorine, barium, strontium, potassium-sodium-chlorine-bromine, nitrogen-iodine, sodium carbonate- sodium sulfate, phosphorus, zirconium-hafnium, silica, feldspars, feldspathoids, zeolites, amphibole-asbestos (asbestiform minerals), olivine-dunite, pyroxene-inosilicates, garnet-group minerals, epidote-group minerals, sillimanite-group minerals, corundum-spinel, diamond, graphite, allophane-imogolite, halloysite, kaolinite-group minerals(kandites), talc-pyrophyllite group, smectitegroup minerals, vermiculite, mica-group minerals, chlorite-group minerals, sepiolite-palygorskite (hormites), jet (lapidary coal), amber.

To allow for a direct correlation of the "Chessboard classification scheme of mineral deposits" [1] and its special edition of digital maps of gemstone deposits [49]; with the current study of placer deposits which is designed as a more detailed treatment of those commodities also of significance for gems and gemstones, the pertinent tables from the "Chessboard classification scheme of mineral deposits" are listed below. The gemstone placer deposits under study in the current review can be linked to the primary magmatic, metamorphic and structure-bound deposits which are the potential source of the gems and gemstones in the placer deposits around the globe.

\section{Classification Scheme of Beryllium Deposits}

1. Magmatic beryllium deposits

(1) Beryl-emerald-euclase-hambergite-bearing granite pegmatites (14a D)

(2) Taaffeite- and emerald-bearing skarns (14c D)

(3) Replacement deposits in volcaniclastic deposits and granites (14b D)

(4) Be-bearing alkaline intrusive rocks (nepheline syenite) (14a E)

(5) Tugtupite-bearing alkaline intrusions (14b E)

(6) Chrysoberyl within rare element pegmatites (14c E)

(7) Beryl-bearing pegmatoids (14d D)

2. Structure-related beryllium deposits 
Aquamarine veins (14a G)

3. Sedimentary beryllium deposits

(1) Regolith-hosted emerald deposits (gemstone) (14a H)

(2) Alluvial-fluvial chrysoberyl placer (14a 1)

(3) Black shale-hosted emerald deposits (gemstone) (14a J)

4. Metamorphic beryllium deposits

(1) Schist-related emerald deposits with or without pegmatitic mobilizates (gemstone) (14a AB)

(2) Chrysoberyl in pegmatitic mobilizates in the contact zone

(1) Metaultrabasic rocks (14b A)

(2) Metapelites (14b J)

\section{Classification Scheme of Boron Deposits}

1. Magmatic boron deposits

(1) Pegmatites bearing tourmaline-danburite-dumortierite-kornerupine mineralization (30a D)

(2) Skarn bearing axinite-serendibite-sinhalite mineralization (30b D)

(3) Contact metasomatic/skarn Fe-B deposits and datolite-danburite mineralization (30b CD)

(4) Metaultrabasic to basic rock bearing datolite-kornerupine mineralization (30d A)

(5) Poudretteite-bearing alkaline magmatic complexes (30a E)

2. Sedimentary boron deposits

(1) Playa lakes and lagoons with B-(As-Sb-Li) brines (hot brine-related) (30b J)

(2) Playa lake with B-(As-Sr-Li) (lacustrine-syn(dia)genetic) (30c J)

(3) Salars with Li-K-Cs-(B) (30a L)

(4) Residual deposits (30b L)

(5) Evaporites/byproduct (30c L)

(6) Volcano-sedimentary B deposits/metamorphosed SEDEX deposit (30e J-30e L)

(7) Boron in plant remains $(30 \mathrm{a} \mathrm{N})$

3. Metamorphic boron deposits

(1) Al-enriched gneisses bearing dumortierite (30e HI)

(2) Mg-enriched schists (whiteschists) bearing kornerupine (30d KL)

(3) Cr-bearing tourmalinites in serpentinite-limestone contact zones (30b A)

(4) Datolite-danburite marble (30e K)

\section{Classification Scheme of Fluorine Deposits}

1. Magmatic deposits

(1) Fluorite deposits related to granitic intrusions and fluorite skarn $\mathrm{W}-\mathrm{Sn}$ and $\mathrm{Pb}-\mathrm{Zn}$ deposits (32e $\mathrm{D}$ )

(2) Fluorite deposits related to U-REE carbonatites and alkaline intrusive rocks (32a E)

(3) Granite-related Be-Nb-Ta-fluorite deposits (32d D)

(4) Pegmatite-hosted F-(Sc) deposits (32a D)

(5) Volcanic-hosted F-U-Mo deposits (32g CD)

(6) Volcanic-hosted topaz (32f D)

(7) Granite-related topaz deposits (gemstone) (32b D)

(8) Intragranitic fluorite deposits (32c D)

(9) Cryolite deposit related to metasomatic A-type granites (32b E)

2. Structure-related deposits

(1) F-bearing mega breccia (32c F)

(2) Epithermal ("hot brine") fluorite breccia veins (32a G)

(3) Epithermal F-(Ba) deposits (maars) (32a F) 
(4) Unconformity-related (shallow veins) Pb-Zn-Ba fluorite deposits (32b G)

(5) Thrustbound and replacement topaz deposits (gemstone) (32c G)

3. Sedimentary deposits

(1) Stratabound $\mathrm{Pb}-\mathrm{Zn}$-Ba fluorite deposits in carbonate rocks (MVT) including replacement deposits ("mantos") (32a K)

(2) Stratabound fluorite-celestite deposits in carbonate rocks (32b K)

(3) Residual and karst-related fluorite deposits

(4) Fluorite cavity-fillings and calcretes (32a H)

(5) Fluorite replacement/calamine deposits (32b H)

(6) Phosphorites with F apatite (32c UK)

(7) Topaz placers (32a I)

\section{Classification Scheme of Phosphate Deposits}

1. Magmatic phosphate deposits

(1) Pegmatite-hosted Li-Fe-Mn-Mg phosphates (in places of gem-quality)

(38a D)

(2) Apatite-bearing Fe deposits (Kiruna-type) (38b CD)

(3) Apatite-bearing titanomagnetite-magnetite deposits (Kola-type) (38a E)

(4) Apatite-bearing REE-Fe deposit in alkaline and carbonatite complexes (Sokli-type) (38b E)

2. Structure-related phosphate deposits

(1) Apatite veins (38a G)

(2) Vein-type remobilisation of apatite of phosphorite deposits (38b G)

3. Sedimentary phosphate deposits

(1) Continental phosphates

(1) Alluvial placers of apatite possessing gem-quality (38a l)

(2) $\mathrm{Nb}-\mathrm{P}-\mathrm{Ti}$ laterites and bauxites $(38 \mathrm{a} \mathrm{H})$

(3) Phoscretes

(1) Apicretes (38c H)

(2) APS-mineral bearing duricusts $(38 \mathrm{~b} \mathrm{H})$

(4) Lacustrine phoscretes

(1) (Fluvial-) lacustrine and bog iron ores (38g H-38g K)

(2) Perennial or organic lakes (38a JK)

(3) Ephemeral lakes (38b I)

(2) Marine phosphates

(1) Guano deposits (38a M)

(2) Carbonate-hosted phosphorites (38e K)

(3) Siliciclastic-hosted phosphorites (38e J)

(4) Phosphate sandstones (38e l)

(5) Marine phosphate-bearing ironstones

(1) Phosphatic bonebeds in oolithic ironstones (Minette-/Wabana types) (38f IJ)

(2) Phosphatic bonebeds in detrital iron ore deposits (38g l)

(3) P-bearing biological gem material (ivory) (38a N)

4. Metamorphic phosphate deposits

(1) Apatite-bearing skarn-like mineralization (regionally metamorphosed limestone) (38c K)

(2) Regionally and contact-metamorphosed phosphorites (38c J)

(3) Lazulite-bearing metasedimentary rocks (38c l)

\section{Classification Scheme of Zirconium and Hafnium Deposits}


1. Magmatic zirconium deposits

(1) Zircon-sapphire-bearing alkali basalt (39 B)

(2) Zr-REE-P-Nb-Ta-F-(Be-Th) carbonatite-alkaline igneous complex (39 E)

2. Sedimentary zirconium deposits

(1) Zircon (hyacinth) placer deposits (39 1)

\section{Classification Scheme of Garnet Deposits}

1. Magmatic garnet deposits

(1) Mg-enriched garnet s.s.s. in kimberlites (47a A)

(2) Garnets in volcanic rocks

(1) Mg-enriched garnet s.s.s. in basic volcanic rocks (47a B)

(2) Fe-enriched garnet s.s.s. in dacite and andesite (47a C)

(3) $\mathrm{Mn}-\mathrm{Fe}-$-enriched garnet s.s.s. in rhyolite (47a D)

(3) Fe-Mn enriched garnet s.s.s. in (granite) pegmatites (47b D)

(4) Ti-enriched garnet s.s.s. in alkaline igneous rocks and carbonatites (47a D)

(5) Fe-Ti-Ca-enriched (hydro) garnet s.s.s. in skarn (47c CD)

2. Structure-related garnet deposits

(1) Mg-enriched garnet s.s.s. in kimberlites (47b EF)

(2) Ca-Fe-enriched garnet s.s.s. in $\mathrm{Cu}$ deposits $(47 \mathrm{~b} \mathrm{G})$

(3) Sedimentary garnet deposits

$\mathrm{Mg}-\mathrm{Fe}-\mathrm{Mn}-\mathrm{Ca}-\mathrm{enriched}$ garnet s.s.s. in alluvial through coastal placer deposits (47b I)

(4) Metamorphic garnet deposits

(1) $\mathrm{Mg}-\mathrm{Cr}$-enriched garnet s.s.s. in meta(ultra)basic igneous rocks (47c A)

(2) Fe-Al-enriched garnet s.s.s. in metapelites (47a IJ)

(3) Ca-Mn-enriched garnet s.s.s. in calcsilicate rocks (47cd K)

(4) Mn-enriched garnet s.s.s. in manganiferous BIF ore deposits (47b J)

(5) V-enriched garnet s.s.s. in carbonaceous slates/schists (47d J)

\section{Classification Scheme of Corundum and Spinel (including Gemstones) Deposits}

1. Magmatic corundum and spinel deposits

(1) High-sulfidation-type deposits adjacent to acidic igneous rocks (50d CD)

(2) Corundum xenolites and sapphire in alkali basalt and anorthoclasites (50a B)

(3) Chrome spinel with ruby and sapphire in ultramafic volcanics (50b A)

(4) Corundum (nepheline) syenite and pegmatites (50b E)

(5) Ruby-spinel Skarn (50c D)

(6) Sapphire in lamprophyres (50d E)

(7) Corundum pegmatites (plumasite + marundite) (49c CD-50a CD)

2. Sedimentary corundum and spinel deposits

(1) Precious corundum and spinel in modern alluvial to alluvial-fluvial placers (50b l)

(2) Paleoplacer (50d 1)

3. Metamorphic corundum and spinel deposits

(1) Sapphirine-corundum meta(ultra)basic rocks (49c A-50c A)

(2) Ruby in Al-enriched meta(ultra) basic igneous rocks

(1) Ruby metaultrabasites-serpentinites (50a A)

(2) Ruby in zoisite amphibolite (50c B)

(3) Ruby in marble (50c K)

(4) Corundum/emery-bearing metaduricrusts 
(1) Corundum-diaspore-spinel metabauxite in marble (50b K)

(2) Sillimanite-corundum metapalaeosol $(49 \mathrm{c} \mathrm{H})$

(3) Corundum-spinel metabauxite (50a H)

(5) Ruby and sapphire in gneisses (50b J)

\section{Classification Scheme of Diamond Deposits}

1. Magmatic deposits

(1) Diamond in komatiites, lamprophyres and other ultrabasic rocks (51b A)

(2) Diamond in peridotites of ophiolite sequences (51c A)

(3) Diamond deposits bound to kimberlites (51a A-51a F)

(4) Diamond deposits bound to lamproites (51a E)

2. Sedimentary deposits

(1) Placer deposits

(1) Alluvial-fluvial and near-shore-marine modern diamond placer deposits (51a I)

(2) Palaeoplacer diamond deposits (51b I)

(3) Alluvial-fluvial carbonado placer (51c I)

3. Metamorphic deposits

(1) Microdiamonds in impact structures (51a N)

(2) Microdiamonds in high-pressure zones (51b N)

(3) Microdiamonds in garnet gneiss (51b J)

(4) Diamond in graphite schist (51c J)

\section{Classification Scheme of Silica Deposits}

1. Magmatic deposits

(1) deposits in basic to acidic volcanic rocks

(1) Hypogene agate-amethyst-rock crystal-opal deposits in basic magmatic rocks (40a B)

(2) Thundereggs in felsic magmatic rocks (40a D)

(3) Supergene opal deposits on top of basic and felsic magmatic rocks (40b B-40b H)

(4) Hypogene zeolite-celadonite-bearing opal deposits in basic to acidic magma tic rocks (40f BCD)

(2) Opal and quartz in volcanic sinter, geyserites and high-sulfidation replacement deposits (40c CD)

(3) Quartz- and semi-precious gemstone pegmatites (40d D)

(4) Glass-bearing pyroclastic and volcanic rocks

(1) Pumice (40g CDE)

(2) Scoria (40g B)

(3) Perlite (40h CD)

2. Structure-related deposits

(1) Unconformity-related shallow quartz veins (40a G)

(2) Deep-seated lineamentary quartz veins (40c G)

3. Sedimentary deposits

(1) Silcretes

(1) Quartz (40a H)

(2) Chalcedony (40c H)

(3) Opal (40d H)

(2) Rock crystal placers (40a 1)

(3) Quartz sand and arenites (40c l)

(4) Limnoquartzite (transitional into volcano-sedimentary deposits) (40e J)

(5) Biogenic silica deposits

(1) Diatomite (40c J)

(2) Radiolarite (40d J) 
(3) Chert (40g J)

(4) Rottenstone/ tripolite (40c K)

4. Metamorphic deposits

(1) (Meta) quartzites (40d l)

(2) Opal concretions in graphite schist (40h J)

(3) Onyx within marble (40d K)

(4) Tektites (40a N)

(5) Zebra rock (40a J)

\section{Classification Scheme of Chromium Deposits}

1. Magmatic chromium deposits

(1) Stratiform chromite deposits (la A)

(2) Podiform chromite deposits ( $1 \mathrm{~b} \mathrm{~A}$ )

(3) Concentric chromite deposits (lc A)

(4) Chrome diopside mineralization in kimberlites (Id A)

2. Sedimentary chromium deposits

(1) $\mathrm{Cr}$ concentration in laterites and saprolites (la $\mathrm{H})$

(2) Mtorolite mineralization $(1 \mathrm{~b} \mathrm{H})$

(3) Chromite placer deposits (la l)

3. Metamorphic chromium deposits

(1) Uvarovite and sphene gem deposits (le A)

\section{Classification Scheme of Olivine Deposits}

1. Magmatic olivine deposits

(1) Dunite (olivine) deposits (45a A)

(2) Peridote (chrysolite) gemstone deposits in

(1) Ultrabasic volcanic rocks (451r A)

(2) Basic volcanic rocks (45b B)

(3) Forsterite Skarn (45d CD)

2. Sedimentary olivine deposits

(1) Peridote placer (45a I)

3. Metamorphic olivine deposits

(1) Olivine in serpentinite (45d A)

(2) Olivine (forsterite) in meta-limestones (45d K)

(3) Ophicalcite (45a K)

\section{Classification Scheme of Epidote Deposits}

1. Magmatic epidote deposits

(1) "Unakite"-bearing granite (48a D)

(2) "Saussurite"-bearing basalt (48a B)

(3) Skarn-like tanzanite deposits (48c CD)

(4) Thulite-piedmontite skarn (48d CD)

(5) Thulite-bearing granite (48b D)

2. Metamorphic epidote-group deposits

(1) Epidote in regional and contact metamorphic epidosite (48c B)

(2) Thulite-piedmontite in Mn-bearing metapelites(48b J)

(3) Thulite-nephrite amphibolite (48b B) 
(4) Zoisite-epidosite in metacarbonates (48b K)

(5) Tanzanite in calcsilicates (48c K)

\section{Classification Scheme of Lithium Deposits}

1. Magmatic lithium and cesium deposits

(1) Pegmatitic Li (including gem spodumene) and Cs deposits (15a D)

(2) Li-Cs-Rb in rhyolitic tuffs with Be and F (15b D)

2. Sedimentary lithium and cesium deposits

(1) Brine deposits and salars (15a L)

(1) Geothermal waters and oil-field formation waters

(2) Li brines within playas in Chile

(2) Clay deposits (15a J)

Hectorite in altered volcaniclastic rocks related to hot-spring activity

\section{Classification Scheme of Amber Deposits}

1. Sedimentary jet and amber deposits

(1) Jet deposits (62 J)

(2) Primary amber deposits (63 J)

(3) Reworked amber deposits (63 I)

The codes (e.g. 14aD, 15aJ) refer to the pertinent sections in the "Chessboard classification scheme of mineral deposits" [1].

\section{References}

1. Dill, H.G. The "chessboard" classification scheme of mineral deposits: Mineralogy and geology from aluminum to zirconium. Earth Sci. Rev. 2010, 100, 1-420. [CrossRef]

2. Buck, S.G.; Minter, W.E.L. Placer formation by fluvial degradation of an alluvial fan sequence: The Proterozoic Carbon Leader placer, Witwatersrand Supergroup, South Africa. J. Geol. Soc. 1985, 142, 757-764. [CrossRef]

3. Roy, P.S. Heavy mineral beach placers in southeastern Australia: Their nature and genesis. Econ. Geol. 1999, 94, 567-588. [CrossRef]

4. Lalomov, A.V.; Tabolitch, S.E. Age determination of coastal submarine placer, Val'cumey, northern Siberia. Creat. Ex Nihilo Tech. J. 2000, 14, 83-90.

5. Burton, J.P.; Fralick, P. Depositional placer accumulations in coarse-grained alluvial braided river systems. Econ. Geol. 2003, 98, 985-1001. [CrossRef]

6. Corbett, I.; Burrell, B. The earliest Pleistocene (?) Orange River fan-delta: An example of successful exploration delivery aided by applied Quaternary research in diamond placer sedimentology and paleontology. Quat. Int. 2003, 82, 63-73. [CrossRef]

7. Dill, H.G.; Khishigsuren, S.; Majigsuren, Yo.; Bulgamaa, J.; Hongor, O.; Hofmeister, W. The diamondiferous peridot olivine-garnet deposit Shavryn Tsaram, Central Mongolia, with special reference to its placer deposits. Z. Gemmol. 2004, 53, 87-104.

8. Dill, H.G.; Melcher, F.; Fuessl, M.; Weber, B. The origin of rutile-ilmenite aggregates ("nigrine") in alluvial-fluvial placers of the Hagendorf pegmatite province, NE Bavaria, Germany. Mineral. Petrol. 2007, 89, 133-158. [CrossRef]

9. Dill, H.G. A review of mineral resources in Malawi: With special reference to aluminum variation in mineral deposits. J. Afr. Earth Sci. 2007, 47, 153-173. [CrossRef]

10. Dill, H.G. Grain morphology of heavy minerals from marine and continental placer deposits, with special reference to Fe-Ti oxides. Sediment. Geol. 2007, 198, 1-27. [CrossRef]

11. Gujar, A.R.; Ambre, N.V.; Mislankar, P.G. Onshore Heavy Mineral Placers of South Maharashtra, Central West Coast of India National Seminar on Exploration, Exploitation, Enrichment and Environment of Coastal Placer Minerals (PLACER-2007); Macmillan India: New Delhi, India, 2007. 
12. Dill, H.G.; Ludwig, R.-R. Geomorphological-sedimentological studies of landform types and modern placer deposits in the savanna (Southern Malawi). Ore Geol. Rev. 2008, 33, 411-434. [CrossRef]

13. Jones, G.; O'Brien, V. Aspects of resources estimation fro mineral sands deposits Transactions of the Institutions of Mining and Metallurgy, Section B. Appl. Earth Sci. 2014, 123, 86-94. [CrossRef]

14. Abzalov, M. Mineral Sands. In Modern Approaches in Solid Earth Sciences; Springer: Heidelberg, Germany, 2016; Volume 12, pp. 427-433.

15. Bern, C.R.; Shah, A.K.; Benzel, W.M.; Lowers, H.A. The distribution and composition of REE-bearing minerals in placers of the Atlantic and Gulf coastal plains, USA. J. Geochem. Explor. 2016, 162, 50-61. [CrossRef]

16. Sitdikova, L.M.; Ibragimov, E.A.; Badrutdinov, O.R.; Khasanova, N.M.; Mukhamatdinov, I.I. Material composition of coastal marine placer deposits of the Arabian Sea Coast (Kollam, Kerala, India). Int. Multidiscip. Sci. GeoConf. Surv. Geol. Min. Ecol. Manag. SGEM 2016, 1, 361-368.

17. Hou, B.; Keeling, J.; Van Gosen, B.S. Geological and exploration models of beach placer deposits, integrated from case-studies of Southern Australia. Ore Geol. Rev. 2017, 80, 437-459. [CrossRef]

18. Milesi, J.P.; Ledru, P.; Marcoux, E.; Mougeot, R.; Johan, V.; Lerouge, C.; Sabate, P.; Bailly, L.; Respaut, J.P.; Skipwith, P. The Jacobina Paleoproterozoic gold-bearing conglomerates, Bahia, Brazil: A hydrothermal shear-reservoir model. Ore Geol. Rev. 2002, 19, 95-136. [CrossRef]

19. Malitc, K.N.; Merkle, R.K.W. Ru-Os-Ir-Pt and Pt-Fe alloys from the Evander Goldfield, Witwatersrand Basin, South Africa: Detrital origin inferred from compositional and osmium-isotope data. Can. Mineral. 2004, 42, 631-650. [CrossRef]

20. Frimmel, H.E. Archean atmospheric evolution: Evidence from the Witwatersrand gold fields, South Africa. Earth Sci. Rev. 2005, 70, 1-46. [CrossRef]

21. Stanaway, K.J. Heavy mineral placers. Min. Eng. 1992, 44, 352-358.

22. Summerfield, M.A. Global Geomorphology; John Wiley \& Sons Inc.: New York, NY, USA, 1991; p. 537.

23. Dill, H.G.; Melcher, F.; Fuessl, M.; Weber, B. Accessory minerals in cassiterite: A tool for provenance and environmental analyses of colluvial-fluvial placer deposits (NE Bavaria, Germany). Sediment. Geol. 2006, 191, 171-189. [CrossRef]

24. Dill, H.G.; Techmer, A.; Weber, B.; Fuessl, M. Mineralogical and chemical distribution patterns of placers and ferricretes in Quaternary sediments in SE Germany: The impact of nature and man on the unroofing of pegmatites. J. Geochem. Explor. 2008, 96, 1-24. [CrossRef]

25. Dill, H.G. Geogene and anthropogenic controls on the mineralogy and geochemistry of modern alluvial-(fluvial) gold placer deposits in man-made landscapes in France, Switzerland and Germany. J. Geochem. Explor. 2008, 99, 29-60. [CrossRef]

26. Dill, H.G.; Klosa, D.; Steyer, G. The “Donauplatin”: Source rock analysis and origin of a distal fluvial Au-PGE (gold-platinum-group-element) placer in Central Europe. Mineral. Petrol. 2009, 96, 141-161. [CrossRef]

27. Dill, H.G.; Steyer, G.; Weber, B. Morphological studies of PGM grains in alluvial-fluvial placer deposits from the Bayerischer Wald, SE Germany: Hollingworthite and ferroan platinum. Neues Jahrb. Mineral. Abh. 2010, 187, 101-110. [CrossRef]

28. Miall, A.D. Principles of Sedimentary Basin Analysis, 3rd ed.; Springer: Berlin, Germany, 1999; p. 616.

29. Galloway, W.E.; Hobday, D.K. Terrigenous Clastic Depositional Systems: Applications to Fossil Fuel and Groundwater Resources; Springer: Berlin, Germany, 1996; p. 489.

30. Panin, N.; Panin, S. Sur la genèse des accumulations des mineraux lourds dans le delta du Danube. Rev. Géogr. Phys. Géol. Dyn. 1969, 11, 511-522.

31. Boyd, R.; Dalrymple, R.; Zaitlin, B.A. Classification of clastic coastal depositional environments. Sediment. Geol. 1992, 80, 139-150. [CrossRef]

32. Dalrymple, R.W. Tidal depositional systems. In Facies Models 4; James, N.P., Dalrymple, R.W., Eds.; Geological Association of Canada: St. John's, NL, Canada, 2010; pp. 201-232.

33. Dalrymple, R.W.; Choi, K. Morphologic and facies trends through the fluvial-marine transition in tide-dominated depositional systems: A schematic framework for environmental and sequence-stratigraphic interpretation. Earth Sci. Rev. 2007, 81, 135-174. [CrossRef]

34. Davis, R.A., Jr.; Dalrymple, R.W. Principles of Tidal Sedimentology; Springer: New York, NY, USA, $2011 ;$ p. 621.

35. Longhitano, S.G.; Mellere, D.; Steel, R.J.; Ainsworth, R.B. Tidal depositional systems in the rock record: A review and new insights. Sediment. Geol. 2012, 279, 2-22. [CrossRef] 
36. Hayes, M.O.; FitzGerald, D.M. Origin, Evolution, and Classification of Tidal Inlets. J. Coast. Res. 2013, 69, 14-33. [CrossRef]

37. Fielding, C.R. Upper flow regime sheets, lenses and scour fills: Extending the range of architectural elements for fluvial sediment bodies. Sediment. Geol. 2006, 190, 227-240. [CrossRef]

38. Evans, A.M. Ore Geology and Industrial Minerals-An Introduction; Blackwell: Oxford, UK, 1993; p. 358.

39. Peel, M.C.; Finlayson, B.L.; McMahon, T.A. Updated world map of the Köppen-Geiger climate classification. Hydrol. Earth Syst. Sci. 2007, 11, 1633-1644. [CrossRef]

40. Slingerland, R. The effects of entrainment on the hydraulic equivalence relationships of light and heavy minerals in sands. J. Sediment. Petrol. 1977, 47, 753-770. [CrossRef]

41. Reid, I.; Frostick, L.E. Role of settling entrainment and dispersive equivalence and of interstice trapping in placer formation. J. Geol. Soc. Lond. 1985, 142, 739-746. [CrossRef]

42. Hughes, M.G.; Keene, J.B.; Joseph, R.G. Hydraulic sorting of heavy-mineral grains by swash on a medium-sand beach. J. Sediment. Res. 2000, 70, 994-1004. [CrossRef]

43. Morton, A.C. Stability of detrital heavy-minerals in Tertiary Sandstones from the North Sea Basin. Clay Miner. 1984, 19, 287-308. [CrossRef]

44. Lång, L.-O. Heavy mineral weathering under acidic soil conditions. Appl. Geochem. 2000, 15, 415-423. [CrossRef]

45. Dill, H.G. Kaolin: Soil, rock and ore: From the mineral to the magmatic, sedimentary, and metamorphic environments. Earth Sci. Rev. 2016, 161, 16-129. [CrossRef]

46. Dill, H.G. An overview of the pegmatitic landscape from the pole to the equator-Applied geomorphology and ore guides. Ore Geol. Rev. 2017, 91, 795-823. [CrossRef]

47. Dill, H.G. Residual clay deposits on basement rocks: The impact of climate and the geological setting on supergene argillitization in the Bohemian Massif (Central Europe) and across the globe. Earth Sci. Rev. 2017, 165, 1-58. [CrossRef]

48. Günther, B. Bestimmungstabellen für Edelsteine, Synthesen, Imitationen; Lenzen: Kirchweiler, Germany, 1988; p. 162.

49. Dill, H.G.; Weber, B. Gemstones and geosciences in space and time. Digital maps to the "Chessboard classification scheme of mineral deposits". Earth Sci. Rev. 2013, 127, 262-299. [CrossRef]

50. Besaire, H. Gites Mineraux de Madagascar; Fascicule; Annales Geologique de Madagascar: Tananarive, Madagascar, 1966; Volume XXXIV, p. 135.

51. Cairncross, B.; Campbell, I.C.; Huizenga, J.M. Topaz, aquamarine, and other beryls from Klein Spitzkoppe, Namibia. Gems Gemol. 1998, 34, 114-125. [CrossRef]

52. Pezzotta, F. Madagaskar Ein Paradies voll mit Mineralien und Edelsteinen; Weise: München, Germany, 1999; Volume 17, pp. 1-96.

53. Grundmann, G. Die Smaragde der Welt. ExtraLapis 2001, 21, 26-37.

54. Kievlenko, E.Y. Geology of Gems; Ocean Publications Ltd.: Littleton, CO, USA, 2003; p. 432.

55. Laurs, B.M.; Simmons, W.B.; Rossman, G.R.; Quinn, E.P.; McClure, S.F.; Peretti, A.; Armbruster, T.; Hawthorne, F.C.; Falster, A.U.; Günther, D.; et al. Pezzottaite from Ambatovita, Madagascar: A new gem mineral. Gems Gemol. 2003, 39, 284-301. [CrossRef]

56. Cairncross, B. Field Guide to Rocks and Minerals of Southern Africa; Struik New Holland Publishing: Cape Town, South Africa, 2004; p. 297.

57. Seifert, A.V.; Žáček, V.; Vrána, S.; Pecina, V.; Zachariáš, J.; Zwaan, J.C. Emerald mineralization in the Kafubu area, Zambia. Czech Geol. Surv. Bull. Geosci. 2004, 79, 1-40.

58. Kuo, C.S. The Mineral Industry of Sri Lanka. In U.S. Geological Survey Minerals Yearbook 2005; U.S. Geological Survey: Reston, FL, USA, 2005; pp. 25.1-25.2.

59. Shigley, J.E.; Laurs, B.M.; Janse, A.J.A.; Elen, S.; Dirlam, D. Gem localities of the 2000s. Gems Gemol. 2010, 46, 188-216. [CrossRef]

60. Walton, L. Exploration Criteria for Colored Gemstone Deposits in the Yukon; Open File 2004-10; Yukon Geological Survey: Whitehorse, YT, Canada, 2004; p. 184.

61. Schumann, W. Gemstones of the World; Sterling Publishing Co.: New York, NY, USA, 1997; p. 280.

62. Gübelin, E.; Erni, F. Gemstones, Symbols of Beauty and Power; Geoscience Press: Tucson, AZ, USA, $2000 ;$ p. 240.

63. Siebel, W.; Schmitt, A.K.; Danišík, M.; Chen, F.; Meier, S.; Weiß, S.; Ero, S. Prolonged mantle residence of zircon xenocrysts from the western Eger rift. Geosci. Nat. 2009, 2, 886-890. [CrossRef] 
64. Pupin, J.P. Zircon and granite petrology. Contrib. Mineral. Petrol. 1980, 73, 207-220. [CrossRef]

65. Dill, H.G. Pegmatites and aplites: Their genetic and applied ore geology. In Ore Geol. Rev.; 2015; Volume 69, pp. 417-561.

66. Proctor, K. Gem pegmatites of Minas Gerais, Brazil: Exploration, occurrence, and aquamarine deposits. Gems Gemol. 1984, 1984, 78-100. [CrossRef]

67. Proctor, K. Chrysoberyl and alexandrite from the pegmatite districts of Minas Gerais, Brazil. Gems Gemol. 1988, 1988, 16-32. [CrossRef]

68. Schmetzer, K.; Caucia, F.; Gilg, H.A.; Coldham, T.S. Chrysoberyl from the New England Placer Deposits, New South Wales, Australia. Gems Gemol. 2016, 52. [CrossRef]

69. Henry, D.J.; Guidotti, C.V. Tourmaline as a petrogenetic indicator mineral: An example from the staurolite-Grade metapelites of NW Maine. Am. Mineral. 1985, 70, 1-15.

70. Henry, D.J.; Dutrow, B.L. Metamorphic tourmaline and its petrologic applications. Rev. Mineral. 1996, 33, 503-557.

71. Hawthorne, F.J.; Henry, D.J. Classification of the minerals of the tourmaline group. Eur. J. Mineral. 1999, 11, 201-216. [CrossRef]

72. Castañeda, C.; César-Mendes, J.; Pedrosa-Soares, A.C. Turmalinas. Soc. Bras. Geol. 2001, 152-179.

73. Basset, A.M. Nepal gem tourmaline. J. Nepal Geol. Soc. 1987, 4, 31-41.

74. UN-ESCAP Geology and Mineral Resources of Nepal. Atlas of Mineral resources of the ESCAP region. UN/ESCAP in coordination with DMG; Commission for the Asia and the Pacific: New York, NY, USA, 1993; Volume 9, p. 107.

75. Aryal, R.K. Current Status of Precious and Semi-Precious Stones of Nepal; Unpublished Report; Ministry of Industry, Department of Mines and Geology: Kathmandu, Nepal, 2001.

76. Kaphle, K.P.; Einfalt, H.C. Prospects of Precious and Semiprecious stones in Nepal Himalaya and their Mining Opportunities. In Proceedings of the 29th Himalaya-Karakoram-Tibet Workshop, Lucca, Italy, 2-4 September 2014; pp. 77-78.

77. Henry, D.J.; Novak, M.; Hawthorne, F.C.; Ertl, A.; Dutrow, B.L.; Uher, P.; Pezzotta, F. Nomenclature of the tourmaline-supergroup minerals. Am. Mineral. 2011, 96, 895-913. [CrossRef]

78. Menzies, M.A. The mineralogy, geology and occurrence of topaz. Mineral. Rec. 1995, 25, 5-53.

79. Dill, H.G.; Busch, K.; Blum, N. Chemistry and origin of veinlike phosphate mineralization, Nuba Mts. (Sudan). Ore Geol. Rev. 1991, 6, 9-24. [CrossRef]

80. Dill, H.G. Heavy mineral response to the progradation of an alluvial fan: Implications concerning unroofing of source area, chemical weathering, and paleo-relief (Upper Cretaceous Parkstein fan complex/SE Germany). Sediment. Geol. 1995, 95, 39-56. [CrossRef]

81. Rozendaal, C.; Philander, A. Mineralogy of heavy mineral placers along the west coast of South Africa. In Proceedings of the 6th International Congress on Applied Mineralogy ICAM 2000, Göttingen, Germany, 17-19 July 2000; pp. 417-420.

82. Philander, C.; Rozendaal, A. Geology of the Cenozoic Namakwa Sands Heavy Mineral Deposit, West Coast of South Africa: A World-Class Resource of Titanium and Zircon. Econ. Geol. 2015, 110, 1577-1623. [CrossRef]

83. Pupin, J.P.; Turco, G. Le zircon, minéral commun significatif des roches endogènes et exogènes. Bull. Minéral. 1981, 104, 724-731.

84. Bossart, P.J.; Meier, M.; Oberli, F.; Steiger, R.H. Morphology versus U-Pb systematics in zircon: A high-resolution isotopic study of a zircon population from a Variscan dyke in the Central Alps. Earth Planet. Sci. Lett. 1986, 78, 339-354. [CrossRef]

85. Benisek, A.; Finger, F. Factors controlling the development of prism faces in granite zircons: A microprobe study. Contrib. Mineral. Petrol. 1993, 114, 441-451. [CrossRef]

86. Bingen, B.; Davis, W.J.; Austrheim, H. Zircon U-Pb geochronology in the Bergen arc eclogites and their Proterozoic protoliths, and implications for the pre-Scandian evolution of the Caledonides in western Norway. Geol. Soc. Am. Bull. 2001, 113, 640-649. [CrossRef]

87. Dill, H.G.; Kaufhold, S.; Lindenmaier, F.; Dohrmann, R.; Ludwig, R.; Botz, R. Joint clay-heavy-light mineral analysis: A tool to investigate the hydrographic-hydraulic regime of the Late Cenozoic deltaic inland fans under changing climatic conditions (Cuvelai-Etosha Basin, Namibia). Int. J. Earth Sci. 2012, 102, 265-304. [CrossRef] 
88. Grew, E.S.; Locock, A.J.; Mills, S.J.; Galuskina, I.O.; Galuskin, E.V.; Hålenius, U. Nomenclature of the garnet supergroup. Am. Mineral. 2013, 98, 785-811. [CrossRef]

89. Wilson, B.S. Colored Gemstones from Canada. Rocks Miner. 2010, 85, 24-43. [CrossRef]

90. Lind, T.; Henn, U.; Bank, H. Spessartine aus Namibia. Neues Jahrb. Mineral. Monatsh. 1993, 1993, 569-576.

91. Gent, M.R.; Alvarez, M.M.; Iglesias, J.J.M.G.; Álvarez, J.T. Offshore occurrences of heavy-mineral placers, Northwest Galicia, Spain. Mar. Georesour. Geotechnol. 2005, 23, 39-59. [CrossRef]

92. Angusamy, N.; Rajamanickam, G.V. Depositional environment of sediments along the southern coast of Tamil Nadu, India. Oceanologia 2006, 48, 87-102.

93. Harben, P.W.; Kužvart, M. Industrial Minerals. A Global Geology; London Industrial Minerals Information Ltd.: London, UK, 1996; p. 462.

94. Dill, H.G. Placer deposits—Sedimentary, mineralogical and economic aspects. In Material Characterization by Solid State Spectroscopy; Hofmeister, W., Dao, N.Q., Quang, V.X., Eds.; The Minerals of Vietnam: Hanoi, Vietnam, 2001; pp. 105-123.

95. Laurs, B.M. Update on some Madagascar gem localities. Gems Gemol. 2000, 36, 165-167.

96. Schwarz, D.; Petsch, E.J.; Kanis, J. Sapphires from Andranondambo region, Madagascar. Gems Gemol. 1996, 32, 80-99. [CrossRef]

97. Yager, T.R. The mineral industry of Madagascar. In U.S. Geological Survey Minerals Yearbook 2003; U.S. Geological Survey: Reston, FL, USA, 2003; pp. 21.1-21.5.

98. Rakotondrazafy, A.F.M.; Giuliani, G.; Ohnenstetter, D.; Fallick, A.E.; Rakotosamizanany, S.; Andriamamonjy, A.; Ralantoarison, T.; Razanatseheno, M.; Offant, Y.; Garnier, V.; et al. Gem corundum deposits of Madagascar: A review. Ore Geol. Rev. 2008, 34, 134-154. [CrossRef]

99. Dill, H.G.; Goldmann, S.; Cravero, F. Zr-Ti-Fe placers along the coast of NE Argentina: Provenance analysis and ore guide for the metallogenesis in the South Atlantic Ocean. Ore Geol. Rev. 2018, 95, 131-160. [CrossRef]

100. Hall, A.M.; Thomas, M.F.; Thorp, M.B. Late Quaternary alluvial placer development in the humid tropics: The case of the Birim Diamond Placer, Ghana. J. Geol. Soc. 1985, 142, 777-787. [CrossRef]

101. Thomas, M.F.; Thorp, M.B.; Teeuw, R.M. Palaeogeomorphology and the occurrence of diamondiferous placer deposits in Koidu, Sierra Leone. J. Geol. Soc. 1985, 142, 789-802. [CrossRef]

102. Boxer, G.L.; Deakin, A.S. Argyle alluvial diamond deposits. AusIMM 1990, 14, 1655-1658.

103. Fazakerley, V.W. Bow River alluvial Diamond deposit. Geol. Miner. Depos. Aust. Papua New Guinea 1990, 14, 1659-1664.

104. Thomas, M.F. Landscape sensitivity in time and space-An introduction. Catena 2001, 42, 83-98. [CrossRef]

105. Teeuw, R.M. Regolith and diamond deposits around Tortiya, Ivory Coast, West Africa. Catena 2002, 46, 111-127. [CrossRef]

106. Bluck, B.J.; Ward, J.D.; De Wit, M.C.J. Diamond mega-placers: Southern Africa and the Kaapvaal craton in a global context. Geol. Soc. Lond. Spec. Publ. 2005, 248, 213-245. [CrossRef]

107. Rau, T.K. Incidence of diamonds in the beach sands of the Kanyakumari Coast, Tamil Nadu. J. Geol. Soc. India 2006, 67, 11-16.

108. Tompkins, L.A.G.; Gonzaga, M. Diamonds in Brazil and a proposed model for the origin and distribution of diamonds in the Coromandel Region, Minas Gerais, Brazil. Econ. Geol. 1989, 84, 591-602. [CrossRef]

109. Mitchell, R.H. Kimberlites and Lamproites: Primary sources of diamond. Geosci. Can. 1991, 18, 1-16.

110. Nixon, H. The morphology and nature of primary diamondiferous occurrences. J. Geochem. Explor. 1995, 53, 41-71. [CrossRef]

111. Svisero, D. Distribution and origin of diamonds in Brazil: An overview. J. Geodyn. 1995, 20, $493-514$. [CrossRef]

112. Delaney, P.J.V. Gemstones of Brazil: Geology and Occurrences; Revista Escola de Minas, Praca Tiradentes; REM: Ouro Preto, Brazil, 1996; Volume 20, p. 125.

113. Tappert, R.; Stachel, T.; Harris, J.W.; Muehlenbachs, K.; Brey, G.P. Placer diamonds from Brazil: Indicators of the Composition of the Earth's Mantle and the distance to their kimberlitic sources. Econ. Geol. 2006, 101, 453-470. [CrossRef]

114. Kopylova, M.G.; Russell, J.K.; Stanley, C.; Cookenboo, H. Garnet from Cr- and Ca-saturated mantle: Implications for diamond exploration. J. Geochem. Explor. 2000, 68, 183-199. [CrossRef]

115. Mafound, R.F. Presence of diamond in the pyrope peridotite, Drekeesh area, Tartous province, NW Syria: A new theory on the origin of diamond. Microchem. J. 2002, 73, 265-271. 
116. Schulz, K.-H.; Adelhardt, W.; Wagner, H. Simbabwe. Rohst. Länderber. 1993, 37, 1-224.

117. Steiner, L. Angola. Rohst. Länderber. 1992, 35, 1-135.

118. Green, T. The World of Diamonds; Willian Morrow and Co.: New York, NY, USA, 1981; p. 300.

119. Erlich, E.I.; Hausel, W.D. Diamond Deposits: Origin, Exploration, and History of Discovery; Society for Mining Metallurgy: Littleton, CO, USA, 2008; p. 374.

120. Porter GeoConsultancy. Namdeb, Sperrgebiet, SW Namibian On-shore and Marine Placer Diamonds. 2004. Available online: http:/ / www.portergeo.com.au/database/ mineinfo.asp? mineid=mn945 (accessed on 15 October 2018).

121. Mcdonald, I.; Boyce, A.J.; Butler, I.B.; Herrington, R.T.; Polya, D.A. (Eds.) Mineral Deposits and Earth Evolution; Geological Society: London, UK, 2005; Volume 248, pp. 213-245.

122. Helmore, R. Diamond mining in Angola. Mineral. Mag. 1984, 7, 530-537.

123. Bamford, M.K. Cenozoic macroplants. Oxf. Monogr. Geol. Geophys. 2000, 40, 351-356.

124. Jacob, J.; Ward, J.D.; Bluck, B.J.; Scholz, R.A.; Frimmel, H.E. Some observations on diamondiferous bedrock gully trap sites on Late Cenozoic, marine-cut platforms of the Sperrgebiet, Namibia. Ore Geol. Rev. 2006, 28, 493-506. [CrossRef]

125. Patyk-Kara, N.G. Placers in the system of sedimentogenesis. Lithol. Miner. Resour. 2002, 37, $429-441$. [CrossRef]

126. Li, X.F.; Chen, Z.Y.; Wang, Y.A.; Zhu, H.P. The primarily study on the genesis of rocked quartz in Donghai, Jiangsu Province: Evidence from fluids inclusions and the Si, O isotope data. Acta Petrol. Sin. 2006, 22, 2018-2028, (In Chinese with English abstract).

127. Li, X.F.; Watanabe, Y.; Wang, C.; Hirano, H.; Zhang, Y. The age of the Donghai rock crystals (clear quartz), eastern China: Constraint from biotite Ar-Ar geochronology. Bull. Geol. Survey Jpn. 2007, 58, 1-6. [CrossRef]

128. Anderson, K.B.; LePage, B.A. Analysis of fossil resins from Axel Heiberg Island, Canadian Arctic. In Amber, Resinite and Fossil Resins; Anderson, K.G., Crelling, J.C., Eds.; American Chemical Society Symposium Series; American Chemical Society: Washington, DC, USA, 1995; Volume 617, pp. 170-192.

129. Paškevicius, J. The Geology of the Baltic Republics; Geological Survey and University of Lithuania: Vilnius, Lithuania, 1997; p. 387.

130. Kharin, G.; Emelyanov, E.M.; Zagorodnich, A.V. Paleogene mineral resources of the SE Baltic Sea and Sambian Peninsula. Z. Angew. Geol. 2004, 2, 64-71.

131. Kosmoswska-Cevanowicz, B. Quaternary amber bearing deposits on the Polish Coast. Z. Angew. Geol. 2004, 2, 73-84.

132. Nirgi, T.; Rosentau, A.; Ots, M.; Vahur, S.; Kriiska, A. A Buried amber finds in the coastal deposits of Saaremaa Island, eastern Baltic Sea-Their sedimentary environment and possible use by Bronze Age islanders. Boreas 2017, 46, 725-736. [CrossRef]

133. Tyson, R. Sedimentary Organic Matter: Organic Facies and Palynofacies; Springer: Dordrecht, The Netherlands, 2012; p. 615.

134. McClenaghan, M.B.; Kjarsgaard, B.A. Indicator mineral and surficial geochemical exploration methods for kimberlite in glaciated terrain: Examples from Canada. Geol. Assoc. Can. 2007, 4, 983-1006.

135. Hutchison, M.T.; Frei, D. Diamondiferous kimberlite from Garnet Lake, West Greenland II: Diamonds and the mantle sample. In Proceedings of the 9th International Kimberlite Conference, Frankfurt, Germany, 10-15 August 2008. Extended Abstract No. 9IKCA-00182.

(C) 2018 by the author. Licensee MDPI, Basel, Switzerland. This article is an open access article distributed under the terms and conditions of the Creative Commons Attribution (CC BY) license (http://creativecommons.org/licenses/by/4.0/). 